\title{
Design and evaluation of non-carboxylate 5-arylidene-2-thioxo-4- imidazolidinones as novel non-competitive inhibitors of protein tyrosine phosphatase 1B
}

\author{
Rosaria Ottanà $^{\mathrm{a}, 1, *}$, Paolo Paoli ${ }^{\mathrm{b}, 1}$, Giulia Lori $^{\mathrm{b}}$, Ilenia Adornato ${ }^{\mathrm{a}}$, Santo Previti ${ }^{\mathrm{a}}$, Alexandra Naß ${ }^{\mathrm{c}}$, \\ Gerhard Wolber ${ }^{\mathrm{c}}$, Rosanna Maccari ${ }^{\mathrm{a}, 1}$ \\ ${ }^{\text {a }}$ Department of Chemical, Biological, Pharmaceutical and Environmental Sciences, University of Messina, Polo Universitario Annunziata, Viale SS. Annunziata, 98168 \\ Messina, Italy \\ ${ }^{\mathrm{b}}$ Department of Experimental and Clinical Biomedical Sciences "Mario Serio", University of Firenze, Viale Morgagni 50, 50134 Firenze, Italy \\ ${ }^{\mathrm{c}}$ Institute of Pharmacy, Computer-Aided Molecular Design, Freie Universitaet Berlin, Koenigin-Luisestr. 2+ 4, 14195 Berlin, Germany
}

\section{A R T I C L E I N F O}

\section{Keywords:}

3-aryl-5-arylidene-2-thioxo-4-imidazolidinones

Protein tyrosine phosphatase 1B

Non-competitive inhibitors

Insulin-sensitizing agents

Cellular assays

\begin{abstract}
A B S T R A C T
Protein tyrosine phosphatase 1B (PTP1B) acts as a negative regulator of insulin and leptin signalling and is crucially involved in the development of type 2 diabetes mellitus, obesity, cancer and neurodegenerative diseases. Pursuing our efforts to identify PTP1B inhibitors endowed with drug-like properties, we designed and evaluated 3-aryl-5-arylidene-2-thioxo-4-imidazolidinones (7) as a novel class of non-carboxylate PTP1B inhibitors. In agreement with our design, kinetic studies demonstrated that selected compounds 7 act as reversible, non-competitive inhibitors of the target enzyme at low micromolar concentrations. Accordingly, molecular docking experiments suggested that these inhibitors can fit an allosteric site of PTP1B that we previously individuated. Moreover, cellular assays demonstrated that compound 7e acts as a potent insulin-sensitizing agent in human liver HepG2 cells. Taken together, our results showed that these non-competitive PTP1B inhibitors can be considered promising lead compounds aimed to enhance druggability of the target enzyme and identify novel antidiabetic drugs.
\end{abstract}

\section{Introduction}

Protein tyrosine phosphatase 1B (PTP1B) is an intracellular enzyme critically involved in the regulation of specific signalling pathways related to cell growth, metabolism, and energy homeostasis [1]. In particular, PTP1B acts as a negative regulator of insulin signalling by dephosphorylating specific phosphotyrosine (pTyr) residues on the activated insulin receptor (IR) and IR substrate proteins, thus controlling the cascade of cellular responses to the hormone [2]. Moreover, in the hypothalamus, PTP1B downregulates the signal of leptin by dephosphorylating JAK2, a kinase associated to leptin receptor, and consequently interrupting downstream events that lead to the transcription of genes involved in feeding and energy homeostasis $[3,4]$.

The overexpression of PTP1B is strictly correlated with development of both insulin and leptin resistance, which are important pathogenic mechanisms underlying the onset and progression of type 2 diabetes mellitus (T2DM) and obesity [5-7]. In accord with this hypothesis, it has been showed that the inhibition or genetic ablation of PTP1B can improve insulin and leptin signalling pathways, resulting in improved sensitivity to both hormones in specific tissues, such as skeletal muscle, liver, adipose tissue and hypothalamus, without producing significant toxic effects [3,8-12].

In addition, chronic inflammation, which is a subclinical condition generally associated to both T2DM and obesity, can positively up-regulate PTP1B expression in adipocytes, hepatocytes, and hypothalamus, thus contributing to exacerbate resistance to both insulin and leptin $[13,14]$. Recently, PTP1B was also found to function as a positive regulator of neuroinflammation, which is considered to be a distinctive feature of neurodegenerative diseases including Alzheimer's disease, Parkinson's disease, and multiple sclerosis $[15,16]$. Compelling evidence demonstrated that insulin-resistance in brain tissues can importantly contribute to cognitive impairment and neurodegenerative processes [17-19].

Furthermore, numerous studies demonstrated that upregulated

\footnotetext{
* Corresponding author.

E-mail address: rottana@unime.it (R. Ottanà).

${ }^{1}$ These Authors contributed equally to the work.
} 
PTP1B expression is significantly associated with the progression of several human tumor types, such as colon and breast cancers, and, accordingly, the inhibition of the enzyme results in better prognostic outcome [20-24].

Therefore, on the whole, numerous biochemical and pharmacological findings validate PTP1B as a promising drug target not only for T2DM and obesity, but also for neurodegenerative diseases and cancer, and support the search for PTP1B inhibitors as novel drug candidates for the treatment of these serious human diseases [25-30].

The development of drug-like inhibitors targeted to the active site of PTP1B as therapeutics has proven to be challenging, mainly due to intrinsic features of the catalytic region of the enzyme.

The catalytic domain of PTP1B contains a high-affinity phosphatebinding loop (P-loop) which includes the signature motif $\mathrm{CX}_{5} \mathrm{R}(\mathrm{S} / \mathrm{T})$. In this short amino acid sequence, the cysteine and arginine residues are essential for the catalytic dephosphorylation mechanism common to all protein tyrosine phosphatases (PTPs) and, thus, are conserved in all members of the PTP family. The flexible WPD loop, containing the catalytic residue Asp181, and the YRD loop, including Tyr46 critical for the recognition of pTyr, surround the catalytic site of PTP1B and crucially participate to the binding of ligands. In particular, upon the binding of substrate, the WPD loop shifts over the pTyr-binding loop, thus allowing the enzyme to assume a "closed" catalytically competent form. A less conserved low-affinity non-catalytic aryl-phosphate binding site was individuated near the catalytic region and can be successfully exploited to enhance the selectivity of inhibitors towards PTP1B over other PTPs [31-33].

The polar nature of the highly conserved catalytic site of PTP1B represents the primary obstacle to the identification of inhibitors endowed with appropriate drug-like properties. This could explain, at least in part, why only few PTP1B inhibitors have been evaluated as drug candidates in clinical trials, so far, and no PTP1B-based drug is currently available for therapy. In the early stage of the search for PTP1B inhibitors, extensive efforts to achieve an efficient inhibition of the target enzyme resulted in the identification of numerous potent inhibitors directed to the catalytic site, mainly through the insertion of anionic pTyr-mimetic moieties on suitable scaffolds. In order to improve the bioavailability of these polar molecules, different design approaches has been exploited, i.e. designing less ionisable and/or more lipophilic inhibitors bearing monoanionic pTyr-mimetics and hydrophobic moieties in their structures $[27,28]$.

An alternative strategy to circumvent the issues associated with inhibitors directed to the PTP1B catalytic centre is the design of ligands able to target non-conserved and less polar allosteric sites. Indeed, allosteric modulation has been proposed as an approach that can significantly improve the druggability of PTP1B $[34,35]$. It is worth noting that the natural aminosterol trodusquemine (MSI-1436, Fig. 1), a promising PTP1B inhibitor which successfully passed phase I clinical trials as an antidiabetic and antiobesity candidate, primarily acts as a noncompetitive PTP1B inhibitor capable to control insulin-resistance and leptin-resistance [36].

A PTP1B allosteric site was first identified by Weissman and coll. in a region between helices $\alpha 3$ and $\alpha 6$ of the enzyme. It has been shown that, upon the binding of non-pTyr-mimetic inhibitors to this site, the enzyme is prevented from assuming the "closed" catalytically competent form. In fact, the closure of the WPD loop, which allows Asp181 to assume a position suitable to carry out its role as acid-base catalyst essential for the dephosphorylation mechanism, in part depends on a series of H-bond interactions between helices $\alpha 3, \alpha 6$ and $\alpha 7$. In the presence of an allosteric inhibitor bound in the region between helices $\alpha 3$ and $\alpha 6$, the helix $\alpha 7$ results to be displaced and disordered and, consequently, the WPD loop is blocked in an "open" inactive conformation [34].

Recently, we have identified a second allosteric site, positioned
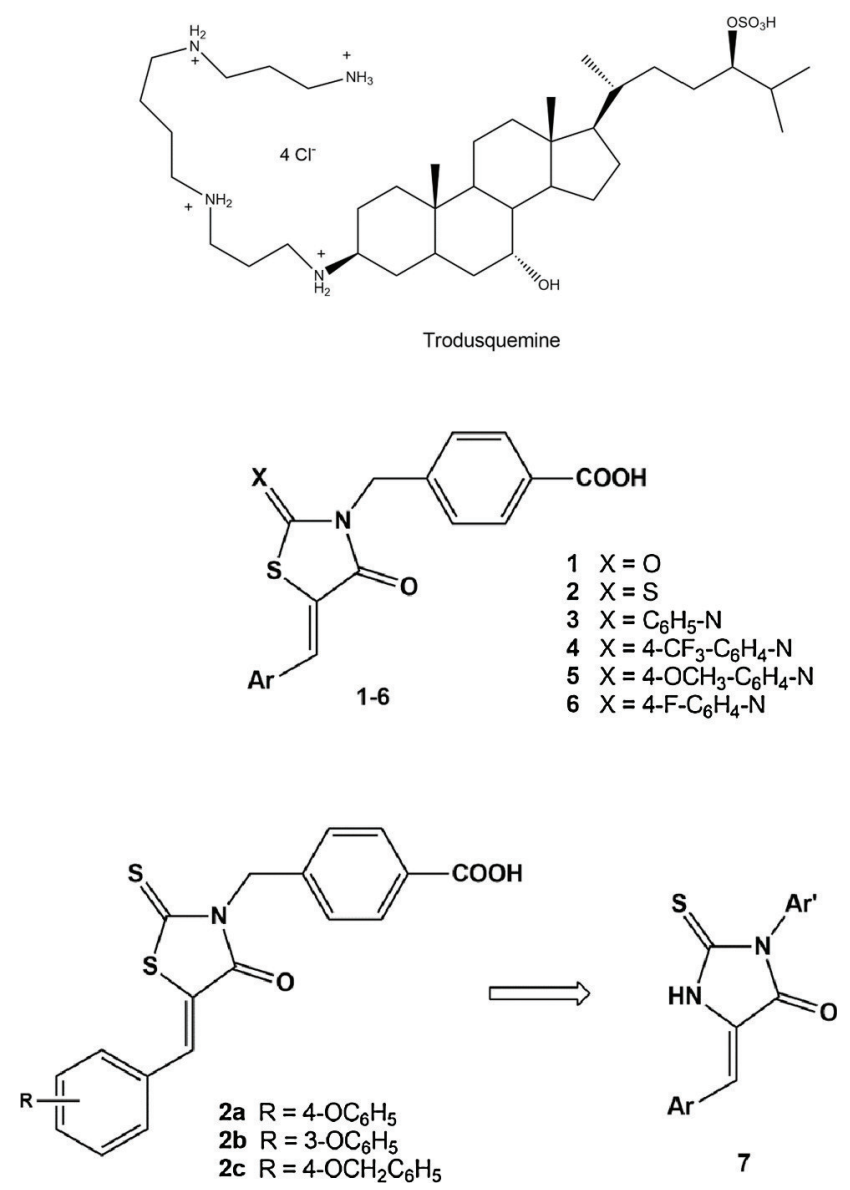

Fig. 1. Structure of trodusquemine and general structures of 5-arylidene-4thiazolidinones 1-6 [37,39-43] and of 3-aryl-5-arylidene-2-thioxo-4-imidazolidinones 7.

between the $\beta$-sheet including Leu71 and Lys73 and a loop consisting of aminoacids Leu204-Pro210, together forming a lipophilic pocket. This pocket is connected to the catalytic site by a short $\beta$-strand, thus it can be inferred that ligand binding to this allosteric region is capable to impair the catalytic functions of PTP1B by influencing the conformation of the active site $[37,38]$.

In the last few years, we investigated 5-arylidene-4-thiazolidinone derivatives (1-6, Fig. 1), which were shown to be potent PTP1B inhibitors [37-43]. Kinetic studies highlighted that the substitution pattern in positions 2 and 5 of the thiazolidinone scaffold can markedly affect the inhibition mechanism of compounds 1-6. Most of them act as competitive PTP1B inhibitors, whereas 2-thioxo-4-thiazolidinone analogues 2a-c (Fig. 1) behaved as mixed type non-competitive inhibitors, being able to bind two not mutually exclusive sites, namely the catalytic centre and the newly-identified allosteric site described above [37]. In particular, the thiocarbonyl group of the 2-thioxo-4-thiazolidinone scaffold (compounds 2) appeared to be more suitable for fitting into the allosteric site than the more bulky 4-fluorophenylimino substituent (compounds 6) [37]. Accordingly, different SARs were observed for 2thioxo-4-thiazolidinones 2 compared to the other 4-thiazolidinone analogues (1, 3-6, Fig. 1) that act via a competitive inhibition mechanism [37,39-43]. In any case, compounds 2 maintained the residue of $p$-methylbenzoic acid as a pTyr-mimetic moiety that makes them capable to bind also the PTP1B catalytic site [37].

The potential of PTP1B allosteric modulators as therapeutics encouraged us to pursue this approach in order to identify new inhibitors capable to control the catalytic function of the target enzyme through a 
non-competitive inhibition mechanism. Therefore, starting from our previous studies, we designed and synthesised 3-aryl-5-arylidene-2thioxo-4-imidazolidinones (7, Fig. 1) as bioisosteres of 5-arylidene-2thioxo-4-thiazolidinones 2 . The 4-methylbenzoic acid residue on N-3 of 4-thiazolidinones 2 was replaced by an aromatic moiety, in order to obtain more lipophilic non-pTyr-mimetic compounds able to interact with the allosteric site, without binding to the catalytic centre. Besides, the replacement of the sulfur atom in position 1 of the 4-thiazolidinone scaffold with the imidazolidinone $\mathrm{NH}$ makes possible the exploitation of further favourable interactions, such as $\mathrm{H}$-bonds, with the target enzyme. The 5-arylidene portion was maintained, since it was able to fit the lipophilic cavity of the newly discovered allosteric site, and different substituents were inserted on the 5-benzylidene ring in order to evaluate the influence of this moiety in the modulation of the inhibitory effects.

The synthesised compounds (7a-w) were evaluated for their in vitro inhibitory activity towards recombinant human PTP1B. Furthermore, representative inhibitors were tested in cultures of human liver HepG2 cells. Kinetic studies were performed in order to determine the inhibition mechanism of compounds 7 . In addition, in silico investigation supported our design and the rationalization of results.

\section{Results and discussion}

\subsection{Chemistry}

The synthesis of (5Z)-3-aryl-5-arylidene-2-thioxo-4-imidazolidinones $(7 \mathbf{a}-\mathbf{w})$ was performed as depicted in Scheme 1 , according to the procedure that we reported recently [44].

3-Aryl-2-thioxo-4-imidazolidinones 8a-e were obtained by the reaction of glycine with the appropriate aryl isothiocyanates, in hydroalcoholic solution under reflux for $24 \mathrm{~h}$. The subsequent Knoevenagel condensation of compounds 8a-e with the appropriate arylaldehydes, in the presence of piperidine as base in refluxing ethanol, afforded 3aryl-5-arylidene-2-thioxo-4-imidazolidinones 7a-w (Scheme 1).

Analytical, spectroscopic data $\left({ }^{1} \mathrm{H}\right.$ and ${ }^{13} \mathrm{C}$ NMR) and X-ray diffraction study confirmed the structure of the newly-synthesized compounds. X-Ray crystallographic study of the 5-(4-phenoxybenzylidene)3-phenyl-2-thioxo-4-imidazolidinone (7g) [44], unambiguously attributed the $Z$ configuration at the chiral axis of derivatives 7 . This result is consistent with previously reported 5-arylidene-2,4-thiazolidinediones [45] and 5-arylidene-2-phenylimino-4-thiazolidinones [46].

${ }^{1} \mathrm{H}$ NMR spectra of 3-aryl-2-thioxo-4-imidazolidinones 8 showed a diagnostic singlet at $4.28-4.33 \mathrm{ppm}$ attributable to $5-\mathrm{CH}_{2}$ protons as

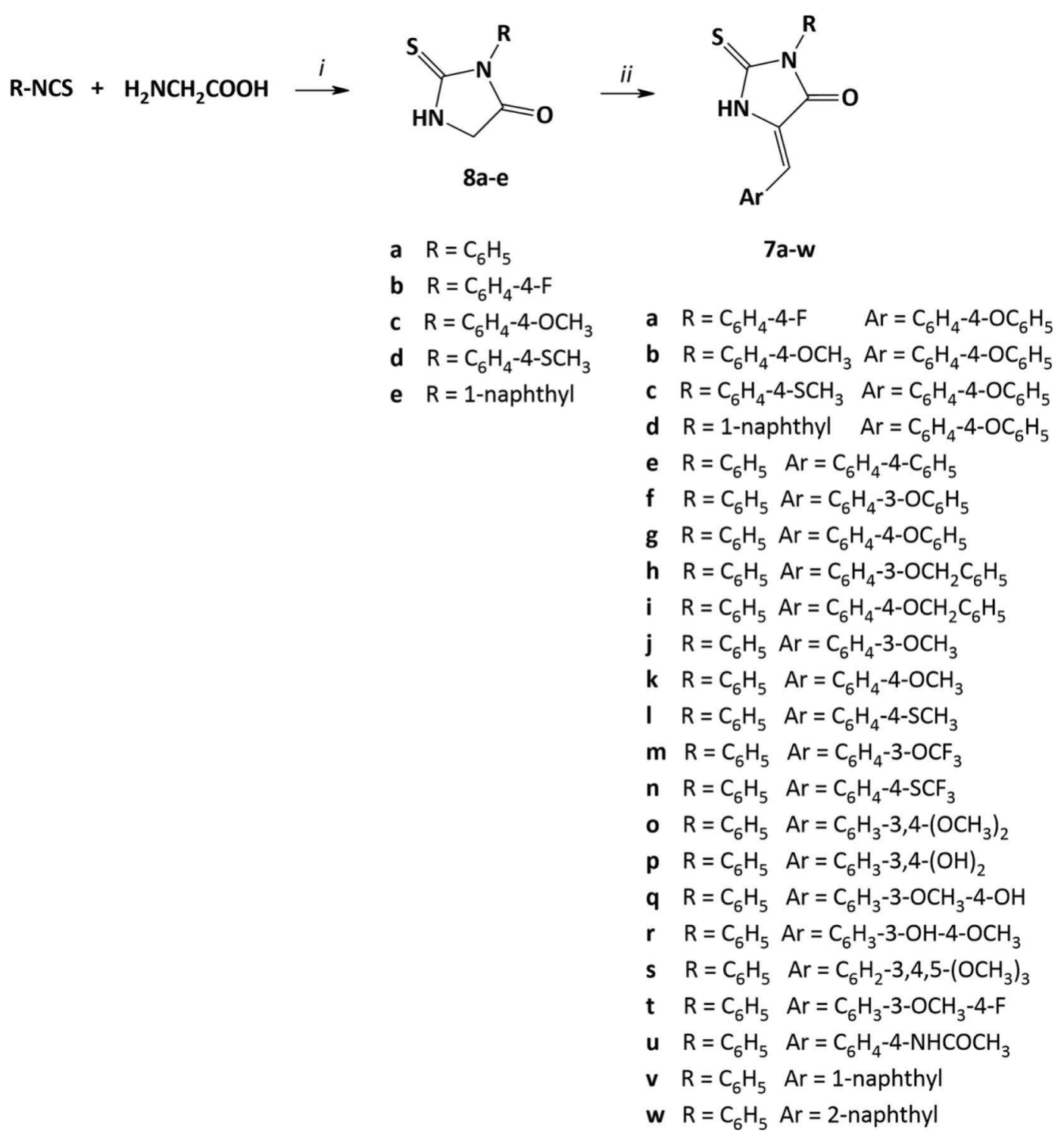

Scheme 1. Synthesis of 3-aryl-5-arylidene-2-thioxo-4-imidazolidinones 7a-w. Reagents and conditions: $i, \mathrm{EtOH} / \mathrm{H}_{2} \mathrm{O}, \Delta$. ii, arylaldehyde, piperidine, EtOH, $\Delta$. 
Table 1

In vitro inhibitory activity of compounds 7a-w against human PTP1B, expressed as $\mathrm{IC}_{50}(\mu \mathrm{M})$.

\begin{tabular}{|c|c|c|c|}
\hline Compd & $\mathbf{R}$ & $\mathrm{Ar}$ & $\mathrm{IC}_{50}(\mu \mathrm{M})$ \\
\hline $7 a$ & $\mathrm{C}_{6} \mathrm{H}_{4}-4-\mathrm{F}$ & $\mathrm{C}_{6} \mathrm{H}_{4}-4-\mathrm{OC}_{6} \mathrm{H}_{5}$ & $3.5 \pm 0.3$ \\
\hline $7 b$ & $\mathrm{C}_{6} \mathrm{H}_{4}-4-\mathrm{OCH}_{3}$ & $\mathrm{C}_{6} \mathrm{H}_{4}-4-\mathrm{OC}_{6} \mathrm{H}_{5}$ & $7.4 \pm 0.4$ \\
\hline $7 c$ & $\mathrm{C}_{6} \mathrm{H}_{4}-4-\mathrm{SCH}_{3}$ & $\mathrm{C}_{6} \mathrm{H}_{4}-4-\mathrm{OC}_{6} \mathrm{H}_{5}$ & $3.5 \pm 0.2$ \\
\hline $7 d$ & 1-naphthyl & $\mathrm{C}_{6} \mathrm{H}_{4}-4-\mathrm{OC}_{6} \mathrm{H}_{5}$ & $15.2 \pm 1.0$ \\
\hline $7 e$ & $\mathrm{C}_{6} \mathrm{H}_{5}$ & $\mathrm{C}_{6} \mathrm{H}_{4}-4-\mathrm{C}_{6} \mathrm{H}_{5}$ & $2.9 \pm 0.2$ \\
\hline $7 f$ & $\mathrm{C}_{6} \mathrm{H}_{5}$ & $\mathrm{C}_{6} \mathrm{H}_{4}-3-\mathrm{OC}_{6} \mathrm{H}_{5}$ & $2.7 \pm 0.24$ \\
\hline $7 g$ & $\mathrm{C}_{6} \mathrm{H}_{5}$ & $\mathrm{C}_{6} \mathrm{H}_{4}-4-\mathrm{OC}_{6} \mathrm{H}_{5}$ & $15.3 \pm 0.5$ \\
\hline $7 \mathrm{~h}$ & $\mathrm{C}_{6} \mathrm{H}_{5}$ & $\mathrm{C}_{6} \mathrm{H}_{4}-3-\mathrm{OCH}_{2} \mathrm{C}_{6} \mathrm{H}_{5}$ & $12.1 \pm 0.90$ \\
\hline $7 \mathrm{i}$ & $\mathrm{C}_{6} \mathrm{H}_{5}$ & $\mathrm{C}_{6} \mathrm{H}_{4}-4-\mathrm{OCH}_{2} \mathrm{C}_{6} \mathrm{H}_{5}$ & $16.8 \pm 1.70$ \\
\hline $7 \mathbf{j}$ & $\mathrm{C}_{6} \mathrm{H}_{5}$ & $\mathrm{C}_{6} \mathrm{H}_{4}-3-\mathrm{OCH}_{3}$ & $>50$ \\
\hline $7 \mathrm{k}$ & $\mathrm{C}_{6} \mathrm{H}_{5}$ & $\mathrm{C}_{6} \mathrm{H}_{4}-4-\mathrm{OCH}_{3}$ & $>50$ \\
\hline 71 & $\mathrm{C}_{6} \mathrm{H}_{5}$ & $\mathrm{C}_{6} \mathrm{H}_{4}-4-\mathrm{SCH}_{3}$ & $5.6 \pm 0.1$ \\
\hline $7 \mathrm{~m}$ & $\mathrm{C}_{6} \mathrm{H}_{5}$ & $\mathrm{C}_{6} \mathrm{H}_{4}-3-\mathrm{OCF}_{3}$ & $49.7 \pm 1.3$ \\
\hline $7 n$ & $\mathrm{C}_{6} \mathrm{H}_{5}$ & $\mathrm{C}_{6} \mathrm{H}_{4}-4-\mathrm{SCF}_{3}$ & $10.2 \pm 0.2$ \\
\hline 70 & $\mathrm{C}_{6} \mathrm{H}_{5}$ & $\mathrm{C}_{6} \mathrm{H}_{3}-3,4-\left(\mathrm{OCH}_{3}\right)_{2}$ & $>50$ \\
\hline $7 p$ & $\mathrm{C}_{6} \mathrm{H}_{5}$ & $\mathrm{C}_{6} \mathrm{H}_{3}-3,4-(\mathrm{OH})_{2}$ & $>50$ \\
\hline $7 q$ & $\mathrm{C}_{6} \mathrm{H}_{5}$ & $\mathrm{C}_{6} \mathrm{H}_{3}-3-\mathrm{OCH}_{3}-4-\mathrm{OH}$ & $>50$ \\
\hline $7 r$ & $\mathrm{C}_{6} \mathrm{H}_{5}$ & $\mathrm{C}_{6} \mathrm{H}_{3}-3-\mathrm{OH}-4-\mathrm{OCH}_{3}$ & $12.2 \pm 0.40$ \\
\hline $7 \mathrm{~s}$ & $\mathrm{C}_{6} \mathrm{H}_{5}$ & $\mathrm{C}_{6} \mathrm{H}_{2}-3,4,5-\left(\mathrm{OCH}_{3}\right)_{3}$ & $>50$ \\
\hline $7 t$ & $\mathrm{C}_{6} \mathrm{H}_{5}$ & $\mathrm{C}_{6} \mathrm{H}_{3}-3-\mathrm{OCH}_{3}-4-\mathrm{F}$ & $>50$ \\
\hline $7 u$ & $\mathrm{C}_{6} \mathrm{H}_{5}$ & $\mathrm{C}_{6} \mathrm{H}_{4}-4-\mathrm{NHCOCH}_{3}$ & $>50$ \\
\hline $7 v$ & $\mathrm{C}_{6} \mathrm{H}_{5}$ & 1-naphthyl & $10.6 \pm 0.5$ \\
\hline $7 w$ & $\mathrm{C}_{6} \mathrm{H}_{5}$ & 2-naphthyl & $6.0 \pm 0.4$ \\
\hline
\end{tabular}

${ }^{\mathrm{a}} \mathrm{IC}_{50}$ values were determined by regression analyses and expressed as means \pm SE of three replicates.

well as the $\mathrm{NH}$ proton of the imidazolidinone ring which resonated at 9.99-10.40 ppm. ${ }^{13} \mathrm{C}$ NMR spectra contributed to the unambiguous attribution of compound structure due to the signals of $5-\mathrm{CH}_{2}$ group (49.7-55.1 ppm) along with the resonance of 2-thiocarbonyl (183.3-183.8 ppm) and 4-carbonyl (171.8-174.8 ppm) groups.

In ${ }^{1} \mathrm{H}$ NMR spectra of compounds $7 \mathbf{a}-\mathbf{w}$, the presence of a singlet attributable to the 5-methylidene proton at $6.53-7.23 \mathrm{ppm}$ along with the disappearance of the $5-\mathrm{CH}_{2}$ signal of intermediate 8 confirmed the structure of compounds. Moreover, the presence of only one set of signals in the NMR spectra of compounds 7 indicated that only the $Z$ isomer was obtained.

\subsection{PTP1B inhibition}

The in vitro evaluation of the РТР1B inhibitory ability of 3-aryl-5arylidene-2-thioxo-4-imidazolidinones (7a-w) was carried out using the human recombinant enzyme and p-nitrophenylphosphate as substrate.

Most of compounds 7a-w showed to be noteworthy inhibitors of the target enzyme (Table 1). Compounds $\mathbf{7 a - c , ~ 7 e , ~ 7 f , ~ 7 1 , ~ a n d ~} \mathbf{7 w}$ were the best PTP1B inhibitors, with $\mathrm{IC}_{50}$ values in the low micromolar range ( $<10 \mu \mathrm{M}$ ). Analogues $\mathbf{7 d}, \mathbf{7 g - i}, \mathbf{7 n}, \mathbf{7 r}$ and $\mathbf{7 v}$ also showed appreciable activity, with $\mathrm{IC}_{50}$ values slightly higher than $10 \mu \mathrm{M}$ (Table 1 ).

The 5-arylidene moiety showed to play a critical role in the inhibition of PTP1B. In fact, the inhibitory effectiveness of 3-phenyl substituted derivatives $7 \mathbf{e}-\mathbf{w}$ showed to be sensitive to the nature and position of substituents on the 5-benzylidene ring. The introduction of an additional aryl ring on the 5-benzylidene moiety (compounds 7e-7i) or an extended aromatic group (compounds $7 \mathbf{v}, 7 \mathbf{w}$ ) on C-5 of the imidazolidinone scaffold generally proved to enhance the affinity toward the target enzyme. The interesting inhibitory potency of 5-(4phenyl)benzylidene substituted compound $7 \mathrm{e} \quad\left(\mathrm{IC}_{50}=2.9 \mu \mathrm{M}\right)$ decreased as a result of the introduction of either an oxygen bridge (compound $7 \mathrm{~g} \mathrm{IC}_{50}=15.3 \mu \mathrm{M}$ ) or an oxymethylene bridge (compound $\left.7 \mathrm{i} \mathrm{IC}_{50}=16.8 \mu \mathrm{M}\right)$. The displacement of the phenoxy group from the para position (compound $\mathbf{7 g}$ ) to the meta one (compound $\mathbf{7 f}$ $\mathrm{IC}_{50}=2.7 \mu \mathrm{M}$ ) proved to be favourable, by reducing the $\mathrm{IC}_{50}$ value almost six-fold. The replacement of the benzyloxy group of compounds $\mathbf{7 h}$ and $\mathbf{7 i}$ with the methoxy one provided compounds $\mathbf{7 j}$ and $\mathbf{7 k}$, respectively, which showed to be inactive. The replacement of the 4methoxy group with the 4-thiomethyl isostere gave rise to compound 71 $\left(\mathrm{IC}_{50}=5.6 \mu \mathrm{M}\right)$, markedly improving the inhibitory ability which, instead, proved to be halved in the case of 4-trifluoromethylthio substituted analogue (compound $\mathbf{7 n} \mathrm{IC}_{50}=10.2 \mu \mathrm{M}$ ).

Among methoxybenzylidene substituted compounds $\mathbf{7 j}, \mathbf{7 k}, \mathbf{7 o}$, and 7q-t, the only active compound was shown to be the 5-(3-hydroxy-4methoxy)benzylidene substituted derivative $7 \mathbf{r}\left(\mathrm{IC}_{50}=12.2 \mu \mathrm{M}\right)$.

Among 5-(4-phenoxybenzylidene) substituted derivatives 7a-d and $7 \mathrm{~g}$, the presence of a substituent of different electronic nature on the 3aryl group (compounds $7 \mathbf{a}-\mathbf{c}$ ) was beneficial for the inhibition of the target enzyme compared to 3-phenyl analogue $\mathbf{7 g}$, whereas the inhibitory potency appeared to be indifferent to the extension of the aromatic system on N-3 (7d vs $\mathbf{7 g}$ ).

Recently, we have selected some of these 3-aryl-2-thioxo-4-imidazolidinones ( $7 \mathrm{~d}, 7 \mathrm{f}, 7 \mathrm{~g}, 7 \mathrm{j}, 7 \mathrm{k}, 71,7 \mathrm{o}, 7 \mathrm{q}, 7 \mathrm{r}, \mathbf{8 a}$ and $8 \mathrm{e}$ ) in order to evaluate them in the context of a search for novel non-covalent inhibitors of human proteasome and immunoproteasome, which are potential targets for the treatment of haematological malignancies [44]. It is worth noting that the SARs that emerged from the PTP1B inhibition assay results are clearly different from those revealed by the evaluation towards proteasome. Indeed, compound $\mathbf{7 f}$, which is the most effective in vitro PTP1B inhibitor of the series, was shown to be almost inactive against human proteasome enzymes; conversely, compound 7o exhibited significant inhibitory properties against human immunoproteasome [44], without affecting the activity of PTP1B at the tested concentrations.

In order to define the action mechanism of PTP1B inhibitors 7, we performed additional tests to verify if representative compounds $\mathbf{7 d}$, $\mathbf{7 e}, \mathbf{7 f}, \mathbf{7 h}, \mathbf{7 i}$, and $\mathbf{7 r}$ behave as reversible or irreversible inhibitors. Data reported in Fig. 2 show that the recovery of PTP1B activity was almost complete in all cases, demonstrating that these compounds behave as reversible inhibitors.

\subsection{Kinetic studies}

Kinetic studies were carried out to determine the type of inhibition of selected compounds $\mathbf{7 d}, \mathbf{7 e}, \mathbf{7 f}, \mathbf{7 h}, \mathbf{7 i}$, and $\mathbf{7 r}$. The double reciprocal plots (Fig. 3) obtained using increasing concentrations of inhibitors demonstrated that compounds $\mathbf{7 d}, \mathbf{7 f}, \mathbf{7 h}$, and $\mathbf{7 r}$ behave as pure non-

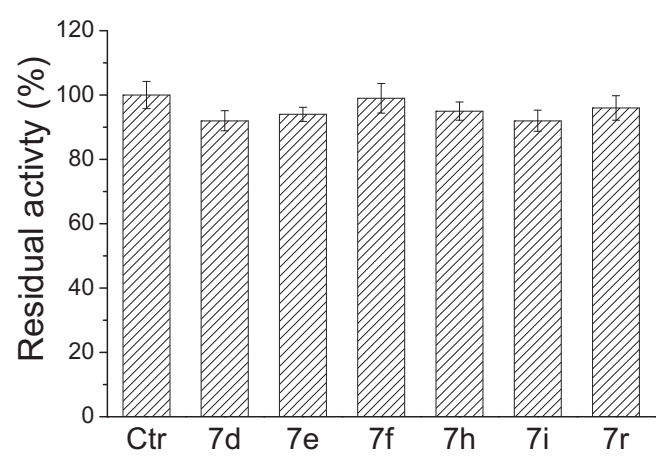

Fig. 2. Inhibition reversibility assay of compounds $\mathbf{7 d}, \mathbf{7 e}, \mathbf{7 f}, \mathbf{7 h}, \mathbf{7} \mathbf{i}$ and $\mathbf{7 r}$. Control experiments were carried out by adding DMSO without inhibitor. Data obtained were normalized respect to the control. Data reported in the fig. represent the mean value \pm S.E.M. of three replicates. Additional details are described in the experimental section. 
A (7d)

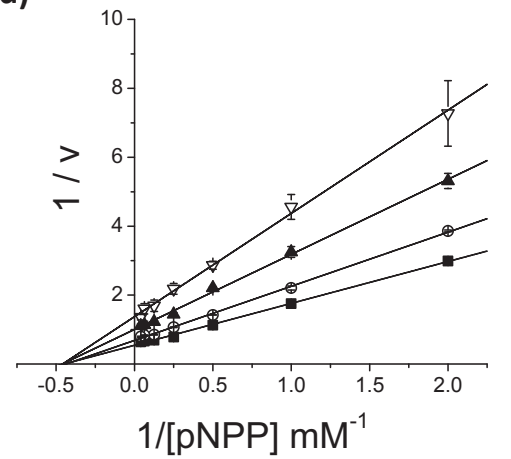

C (7f)

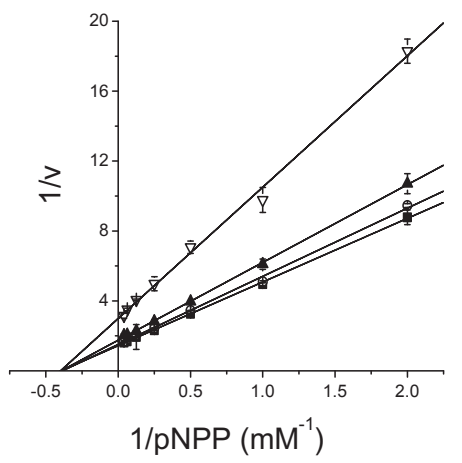

$E(7 i)$

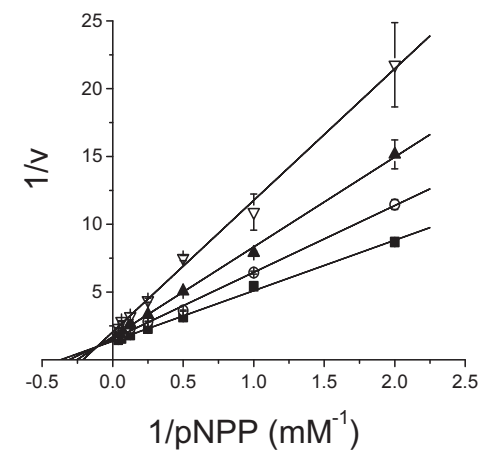

B (7e)

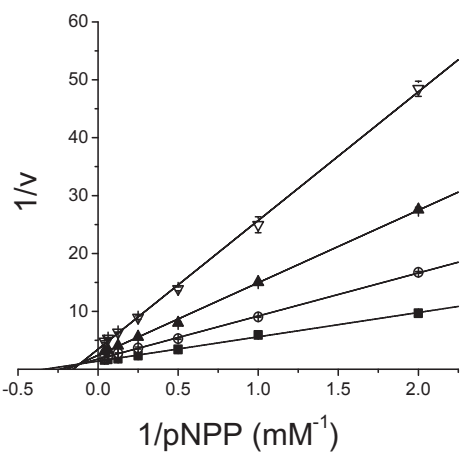

D (7h)

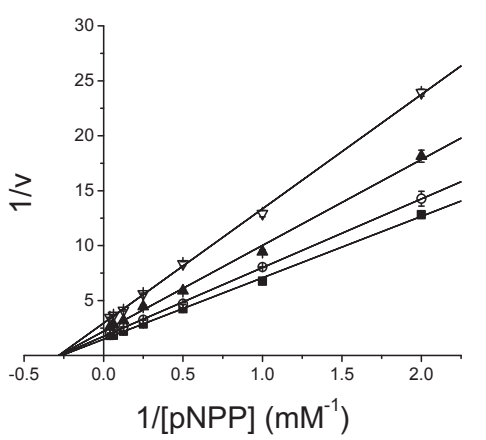

$F(7 r)$

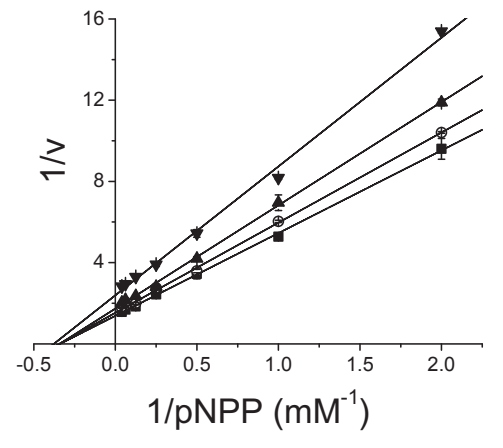

Fig. 3. Double reciprocal plots obtained using PTP1B. (A) compound 7d: $\mathbf{\square}, 0 \mu \mathrm{M} ; \mathrm{O}, 6 \mu \mathrm{M} ; \mathbf{\Lambda}, 12 \mu \mathrm{M} ; \nabla, 24 \mu \mathrm{M}$. (B) compound 7e: $\mathbf{\square}, 0 \mu \mathrm{M} ; \bigcirc, 1 \mu \mathrm{M} ; \mathbf{\Lambda}, 3 \mu \mathrm{M} ; \nabla$, $5 \mu \mathrm{M}$. (C) compound 7f: $\mathbf{\square}, 0 \mu \mathrm{M}$; O, $2.5 \mu \mathrm{M}$; $\mathbf{\Delta}, 5 \mu \mathrm{M} ; \nabla, 10 \mu \mathrm{M}$. (D) compound $7 \mathrm{~h}: \mathbf{\square}, 0 \mu \mathrm{M}$; O, $3 \mu \mathrm{M} ; \mathbf{\Delta}, 5 \mu \mathrm{M} ; \nabla, 7 \mu \mathrm{M}$. (E) compound 7i: $\mathbf{\square}, 0 \mu \mathrm{M}$; O, $1 \mu \mathrm{M}$; $\mathbf{\Lambda}$, $2 \mu \mathrm{M} ; \nabla, 4 \mu \mathrm{M}$. (F) compound $7 \mathrm{r}: \mathbf{\square}, 0 \mu \mathrm{M} ; \mathrm{O}, 2.5 \mu \mathrm{M} ; \Delta, 5 \mu \mathrm{M} ; \nabla, 7.5 \mu \mathrm{M}$.

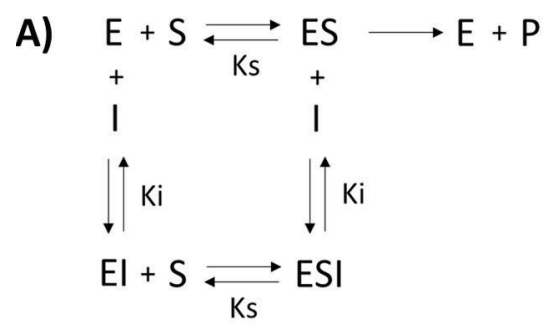

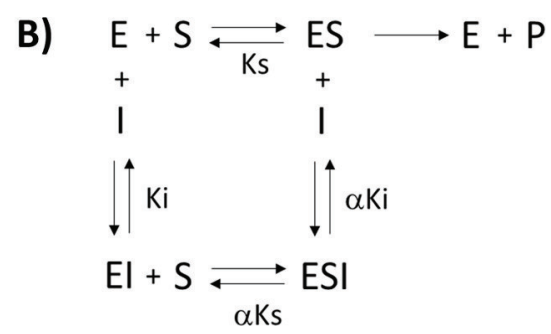

Scheme 2. (A) non-competitive inhibition; (B) mixed type non-competitive inhibition. E, free enzyme; ES, enzyme-substrate complex; EI, enzyme-inhibitor complex; ESI, enzyme-substrateinhibitor ternary complex; P, reaction product; Ks, dissociation constant of enzyme-substrate complex; Ki, dissociation constant of EI complex; $\alpha \mathrm{Ks}$ and $\alpha \mathrm{Ki}$, dissociation constants of enzyme-substrate-inhibitor complex $(\alpha>1)$. competitive inhibitors (see Scheme 2A). In fact, experimental data obtained using increasing inhibitor concentrations describe straight lines intersecting one each other in a point on the $\mathrm{x}$ axis (Fig. 3A, C, D and F). Moreover, the tested compounds determine the decrease of Vmax, without affecting $\mathrm{Km}$ values appreciably (see Supplementary material). On the other hand, we found that compounds $7 \mathrm{e}$ and $\mathbf{7 i}$ show a different behaviour, since they affect both $\mathrm{Km}$ and Vmax parameters (see Supplementary material). Moreover, double reciprocal plot analysis revealed that data points described straight lines intersecting one each other in a point located in the left quadrant (Fig. 3B and E). Together, these evidences showed that compounds $7 \mathbf{e}$ and $\mathbf{7} \mathbf{i}$ behave as mixedtype non-competitive inhibitors (Scheme 2B).

Among the pure non-competitive inhibitors, compounds $\mathbf{7 f}, \mathbf{7 h}$, and $7 \mathrm{r}$ bear a substituent in the meta position of the 5-benzylidene ring, while the mixed-type inhibitors $\mathbf{7 e}$ and $\mathbf{7 i}$ are para substituted analogues. This might suggest that the substitution pattern of the 5-arylidene 


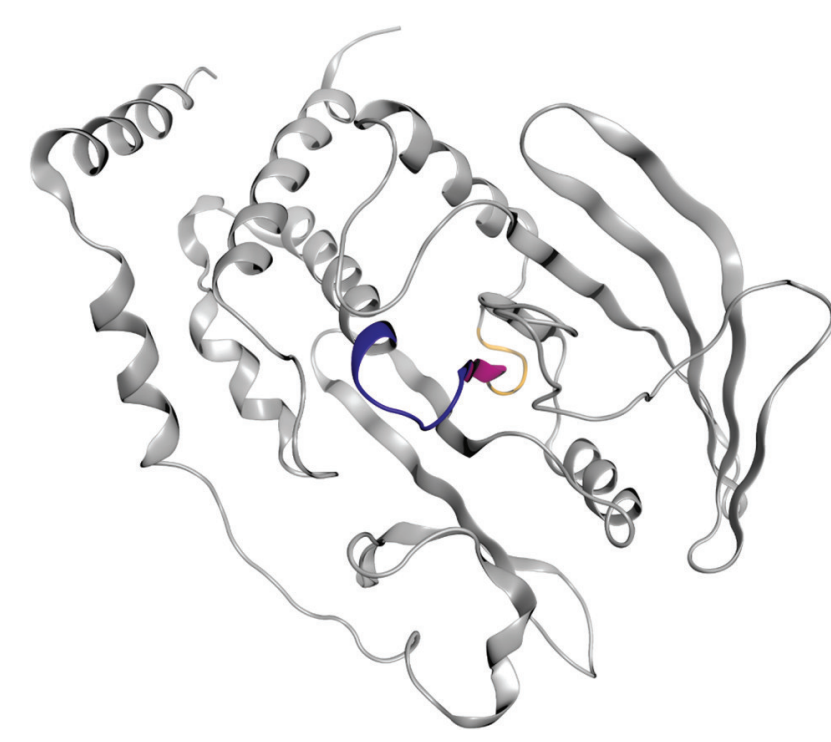

Fig. 4. PTP1B structure (backbone) based on a crystal structure (PDB code 1Q6T) [32]; catalytic loop highlighted in violet, lipophilic loop belonging to the recently suggested allosteric site in yellow, connecting beta strand in pink.

moiety represents a structural feature that is able to influence the action mechanism of these inhibitors. The aryl group on N-3 of the imidazolidinone scaffold might also play a role in determining the inhibition mechanism. In fact, compound $\mathbf{7 d}$, although bearing a phenoxy group in the para position of the 5-benzylidene ring, behaved as a pure noncompetitive inhibitor. It could be inferred that the 1-naphtyl group on N-3 may affect the different interaction mode with the enzyme, compared to the phenyl one.

\subsection{Molecular modelling study}

The main structural difference between the previously investigated PTP1B inhibitors (1-6) and compounds 7 is the lack of a carboxyl pTyrmimetic moiety. Due to the polar properties of the PTP1B active site [47], the lack of a terminal ionisable group in the new compounds should direct preferentially to an allosteric mechanism of inhibition. Accordingly to our design hypothesis and kinetic study reported above, docking experiments revealed that, for compounds 7 , consistent poses can only be found in the allosteric site positioned between Leu71-Lys73 and Leu204-Pro210 that we reported in our previous studies (Fig. 4) $[37,38]$. In this site, the aromatic moiety in position 3 of the 2-thioxo-4imidazolidinone core is buried into the lipophilic pocket delimitated by Pro206 and Pro210, while the 4-carbonyl group forms a hydrogen bond with the side chain of Ser80 and Lys73. The 2-thiocarbonyl group interacts with the lipophilic pocket and could form weak hydrogen bonds with the side chain of Gln78. Figs. 5 to 8 depict this interaction mode for compounds $\mathbf{7 f}, \mathbf{7 h}, \mathbf{7 i}$ and $\mathbf{7 r}$. Compound $\mathbf{7 f}$ shows a slightly more compact binding mode than compounds $\mathbf{7 h}$ and $\mathbf{7} \mathbf{i}$, due to the shorter substituent, resulting in higher shape complementarity of the protein and the bound ligand, which could explain its higher activity.

\subsection{Ex vivo assay}

Compounds $\mathbf{7 e}$ and $\mathbf{7 f}$, which were shown to be the most potent in vitro PTP1B inhibitors among compounds 7 , were selected to be evaluated in human liver HepG2 cell cultures. First, we evaluated the cytotoxicity of these compounds using MTT assay. To this aim, HepG2 cells were incubated in the presence of both compounds for $24 \mathrm{~h}$, and then analysed to evaluate cells viability. The results of this assay confirmed that compounds $\mathbf{7 e}$ and $\mathbf{7 f}$ did not impair cell viability (data not shown).

Then, we analysed the effect of $7 \mathbf{e}$ and $\mathbf{7} \mathbf{f}$ on insulin cell signalling pathway. HepG2 cells were incubated with both compounds for $1 \mathrm{~h}$, and then stimulated (lanes 3 and 4) or not (lanes 1 and 2) with insulin (Fig. 9). After treatment, the phosphorylation levels of Akt, which is a donwnstream protein of the insulin signalling pathway, was determined using specific antibodies (Fig. 9). We found that: (i) in the absence of insulin, treatment with compound 7e slightly increases the phosphorylation levels of Akt (lanes 9 and 10); (ii) compound 7e enhances the effectiveness of insulin, as demonstrated by the strong increase of phosphorylation levels of Akt in cells pre-incubated with compound 7e and then stimulated with insulin (lanes 11 and 12). These results clearly indicate that, in HepG2 cells, compound 7e acts as a potent insulinsensitizing agent, also showing weak insulin mimetic activity. Conversely, no relevant increase of phosphorylation levels of Akt was detected after treatment of the tested liver cells with compound $\mathbf{7 f} \mathbf{f}$, either when it was administrated alone (lanes 5 and 6) or in combination with insulin (lanes 7 and 8) (Fig. 9).

\section{Conclusions}

PTP1B plays critical roles in controlling insulin and leptin signaling pathways and it has been demonstrated that its inhibition or deletion can improve tissue response to these hormones, providing a promising therapeutic strategy aimed to counteract the development of diabetes, obesity, neuroinflammation and cancer.

Considering that the highly conserved polar catalytic site poses challenges in the identification of drug-like inhibitors, the identification of a new non-catalytic site represents an intriguing opportunity for the design of non-competitive PTP1B inhibitors potentially endowed with better bioavailability, compared to pTyr-mimetic inhibitors directed to the active site.

In continuing our search for PTP1B inhibitors, we designed and synthesized novel 3-aryl-5-arylidene-2-thioxo-4-imidazolidinones (7) as isosteres of selected 4-[(5-arylidene-4-oxo-2-thioxothiazolidin-3-yl) methyl]benzoic acids 2, which had proved to be effective allosteric inhibitors of PTP1B [37]. 4-imidazolidinone derivatives 7 were designed as non-carboxylate analogues of 2 lacking of the benzoic acid moiety responsible for active site-directed enzyme inhibition. Moreover, the calculated Lipinski "rule of five" [48] parameters of compounds 7 (see Supplementary material) appear to be consistent with suitable drug-like properties.

The results of inhibition assays indicated that most of compounds 7 were interesting inhibitors of PTP1B. Compounds 7a-c, 7e, 7f, 71, and $7 \mathrm{w}$ proved to inhibit PTP1B in the low micromolar range. The nature and position of substituents on 5-arylidene moiety as well as on N-3 were shown to play a critical role in the interaction with PTP1B enzyme. The presence of an additional aryl ring on the 5-benzylidene group or a naphthyl moiety generally proved to improve enzyme inhibition. Moreover, the substituents on the 5-arylidene moiety of compounds 7 displayed to influence the mechanism of PTP1B inhibition.

Notably, kinetic studies highlighted that compounds $\mathbf{7 f}, \mathbf{7 h}$ and $\mathbf{7 r}$ act as reversible, pure non-competitive inhibitors binding to the allosteric site positioned between Leu71-Lys73 and Leu204-Pro210 that we identified in a previous study [37]. Compounds 7e and $7 \mathbf{i}$ behave as reversible, mixed-type non-competitive inhibitors.

Tests carried out on human liver HepG2 cells showed that 3-phenyl5-(4-phenylbenzylidene)-2-thioxo-4-imidazolidinone (7e) possesses significant insulin-sensitizing activity. Indeed, when compound 7e was administered in combination with insulin, a very strong increase of Akt phosphorylation levels was observed. Conversely, treatment of HepG2 cells with compound 7e alone causes only a slight increase in Akt 


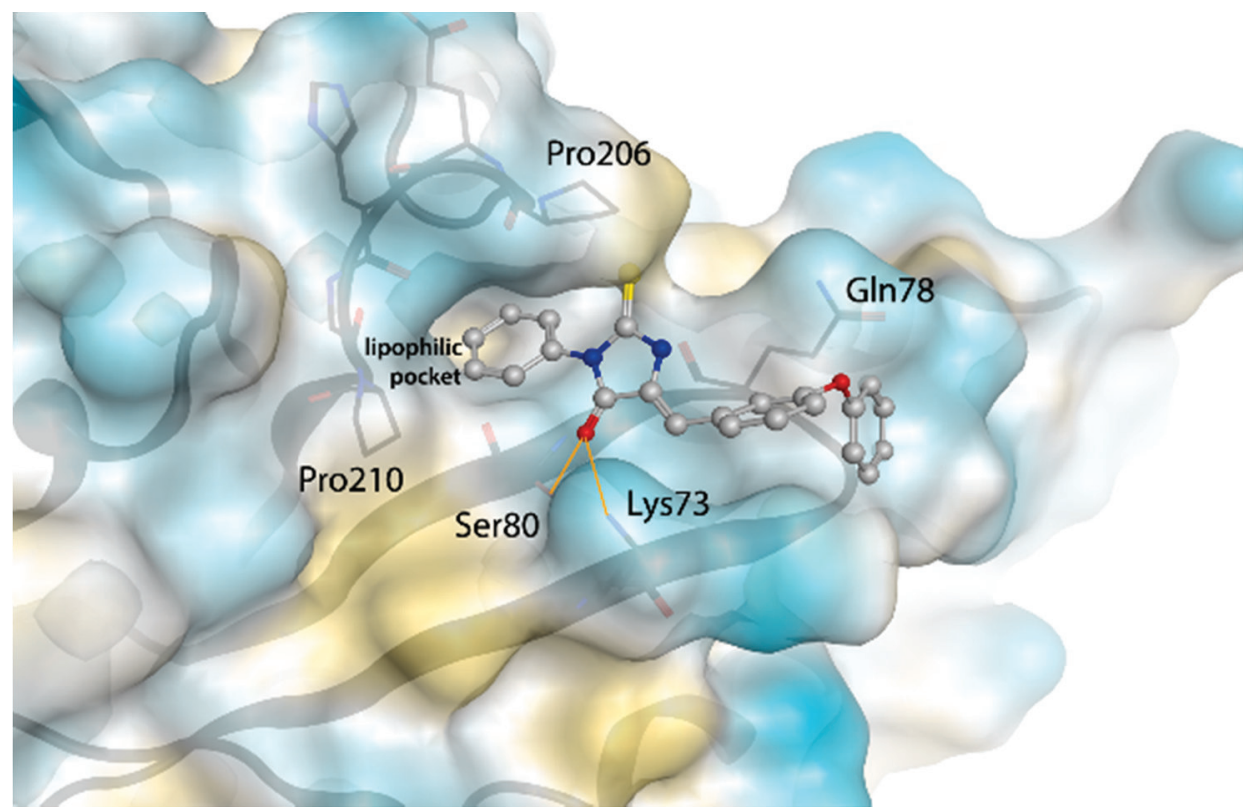

Fig. 5. Docking pose of compound $7 \mathrm{f}$ in an allosteric binding site of PTP1B. Surface coloring by hydrophilicity (cyan)/lipophilicity (sand); hydrogen bonds depicted as yellow lines.

phosphorylation. Taken together, these results suggested that compound $7 \mathbf{e}$ behaves mainly as a potent insulin-sensitizing agent. Notably, the insulin-sensitizing activity of compound $7 \mathrm{e}$ was shown to be markedly higher than those of thiazolidinone analogues that we previously investigated $[37,42,43]$. This finding suggests that compound $7 \mathrm{e}$ can be assumed as a promising lead compound of a new class of noncompetitive inhibitors of PTP1B.

Since non-competitive inhibition of PTP1B is considered an attractive approach to be exploited with the aim of improving the druggability of this target enzyme, this result represents an interesting starting point to further develop novel drug candidates allosterically targeted to this phosphatase.

\section{Materials and methods}

\subsection{Chemistry}

Melting points were recorded on a Kofler hot-stage apparatus and are uncorrected. TLC controls were carried out on precoated silica gel plates (F 254 Merck). Rf values were determined by using a mixture of

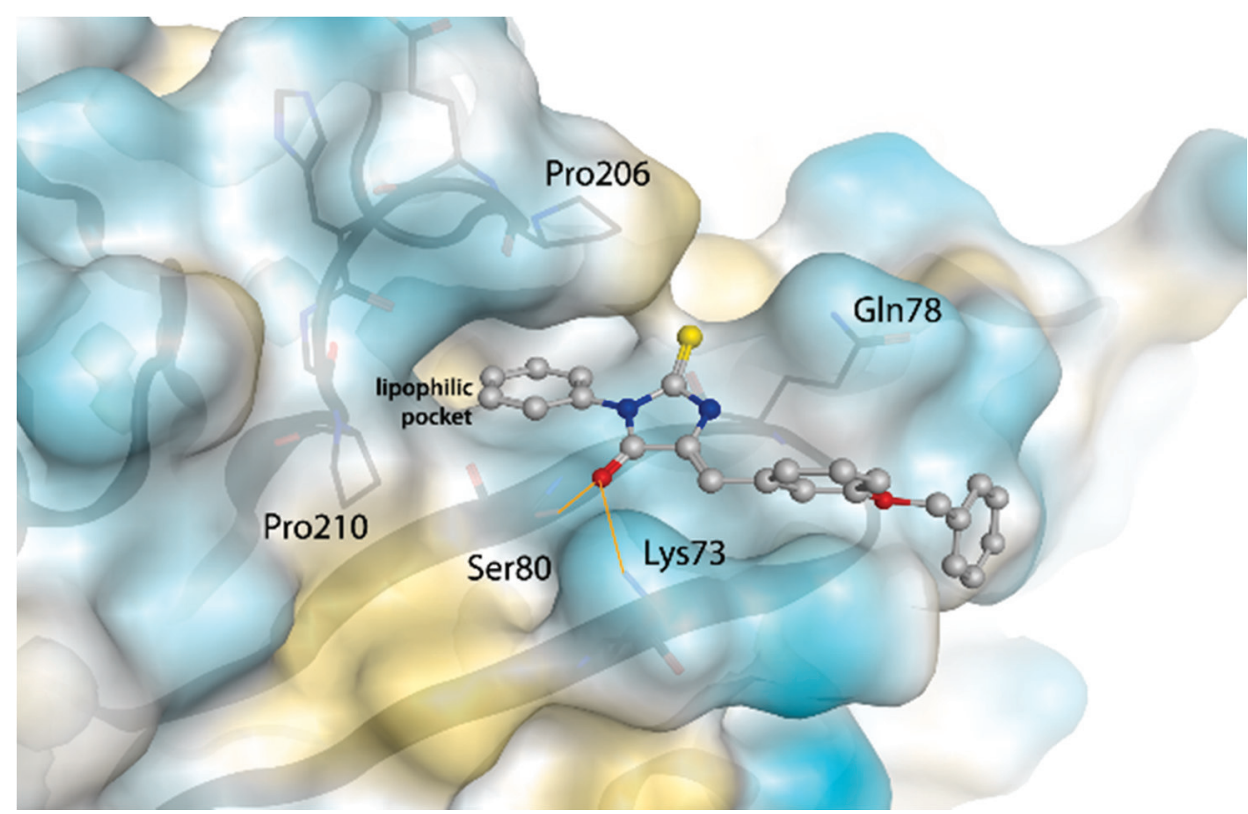

Fig. 6. Docking pose of compound $7 \mathrm{~h}$ in an allosteric binding site of PTP1B. Surface coloring by hydrophilicity(cyan)/lipophilicity(sand); hydrogen bonds depicted as yellow lines. 


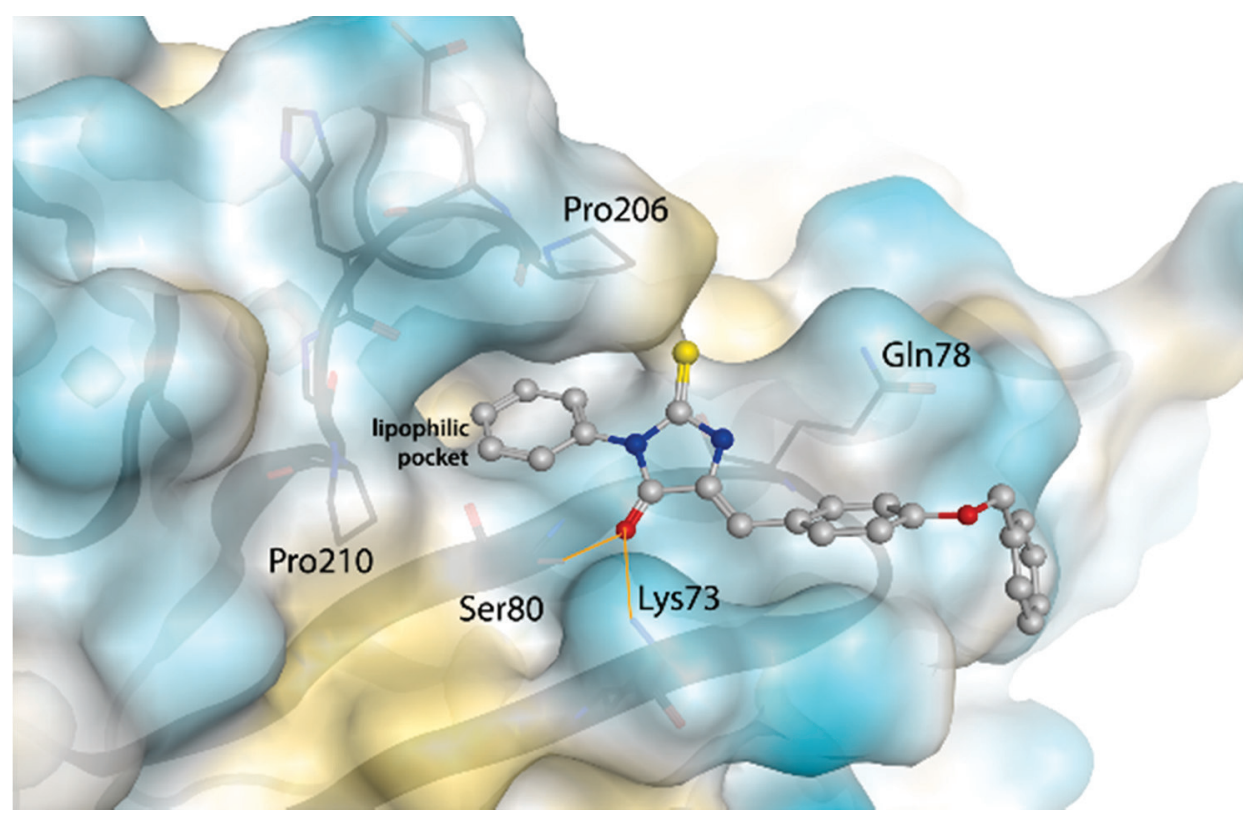

Fig. 7. Docking pose of compound 7i in an allosteric binding site of PTP1B. Surface coloring by hydrophilicity (cyan)/lipophilicity (sand); hydrogen bonds depicted as yellow lines.

diethyl ether/n-hexane (6/4) as eluent. Combustion analyses (C, H, N), determined by means of a C. Erba mod. 1106 elem. Analyzer, were within $\pm 0.4 \%$ of the theoretical values. ${ }^{1} \mathrm{H}$ and ${ }^{13} \mathrm{C}$ NMR spectra were recorded on a Varian $300 \mathrm{MHz}$ spectrometer operating at frequencies of 300.13 and $75.47 \mathrm{MHz}$, respectively, or on a Varian $500 \mathrm{MHz}$ spectrometer operating at 499.74 and $125.73 \mathrm{MHz}$, respectively. Chemical shifts $\delta$ are given in ppm and coupling constants are expressed in Hz. All the spectra were phased, baseline was corrected where necessary and DMSO- $d_{6}$ signals were used as reference for both ${ }^{1} \mathrm{H}$ and ${ }^{13} \mathrm{C}$ spectra. All exchangeable protons were confirmed by addition of $\mathrm{D}_{2} \mathrm{O}$. Unless stated otherwise, all materials were obtained from commercial suppliers and used without further purification. The purity of synthetic compounds was established as $\geq 95 \%$ by combustion analysis.

Compounds $7 \mathrm{~d}, 7 \mathrm{f}, 7 \mathrm{~g}, 7 \mathrm{j}, 7 \mathrm{k}, 71,7 \mathrm{o}, 7 \mathrm{q}, 7 \mathrm{r}, 8 \mathrm{a}$ and $8 \mathrm{e}$ were synthesised according to our previously reported procedure and their chemical-physical data are reported in Ref. 44.

Compounds $7 \mathrm{e}, \mathbf{7 i}, \mathbf{7 p}, \mathbf{7 s}, \mathbf{7 u}, \mathbf{7 v}, \mathbf{7 w}$ are commercially available and CAS numbers are assigned; however, their synthetic procedures, chemical properties and NMR characterization are not available in literature (except the synthesis and ${ }^{1} \mathrm{H}$ NMR data of $\mathbf{7 p}$ [49]).

\subsubsection{General procedure for the synthesis of 3-aryl-2-thioxo-4- imidazolidinones $(\mathbf{8} \boldsymbol{b}-\boldsymbol{d})$}

A mixture of the appropriate aryl isothiocyanate $(5.32 \mathrm{mmol})$ and glycine $(6.66 \mathrm{mmol})$ in hydroalcoholic ( $35 \%$ water vol/vol) solution was heated under reflux for $24 \mathrm{~h}$. The solvent was then evaporated under reduced pressure. The solid residue was washed, dried and recrystallized in methanol providing pure compounds 8.

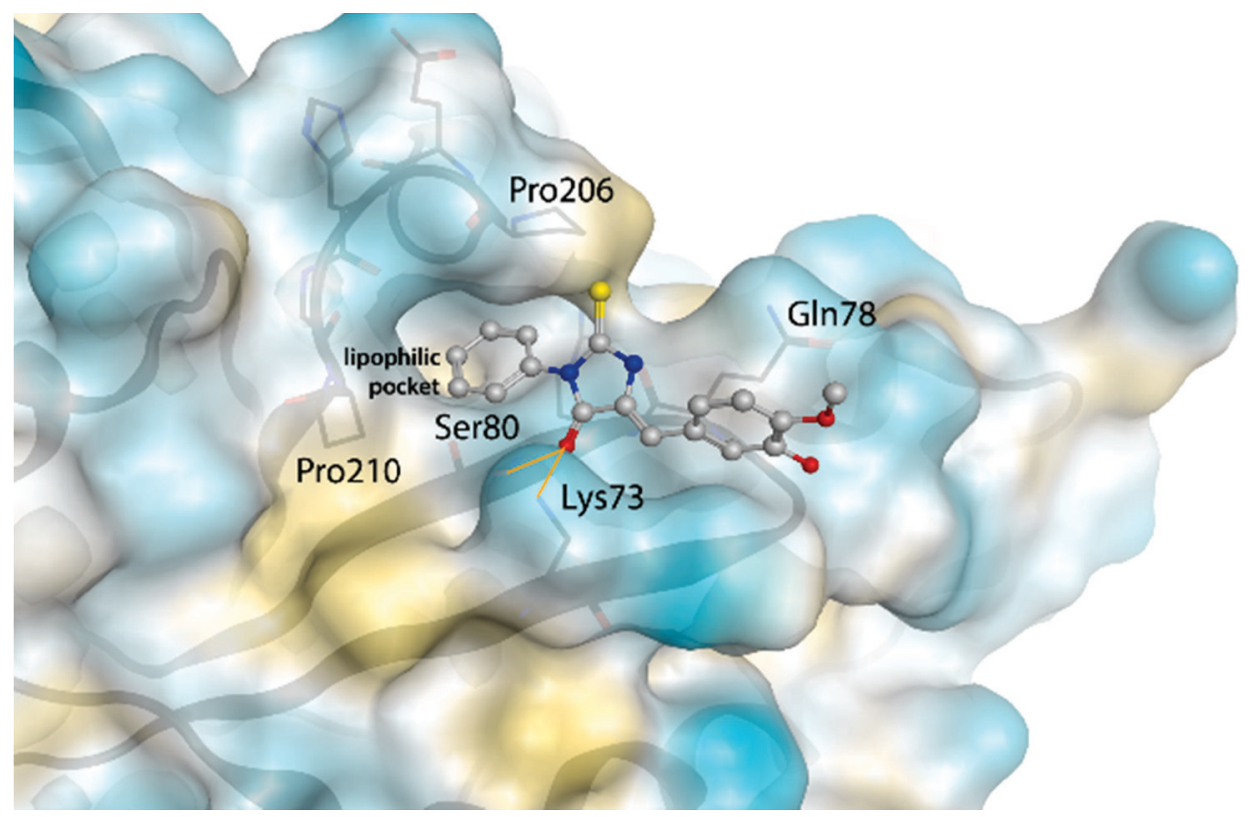

Fig. 8. Docking pose of compound $7 \mathrm{r}$ in an allosteric binding site of PTP1B. Surface coloring by hydrophilicity (cyan)/lipophilicity (sand); hydrogen bonds depicted as yellow lines. 
A

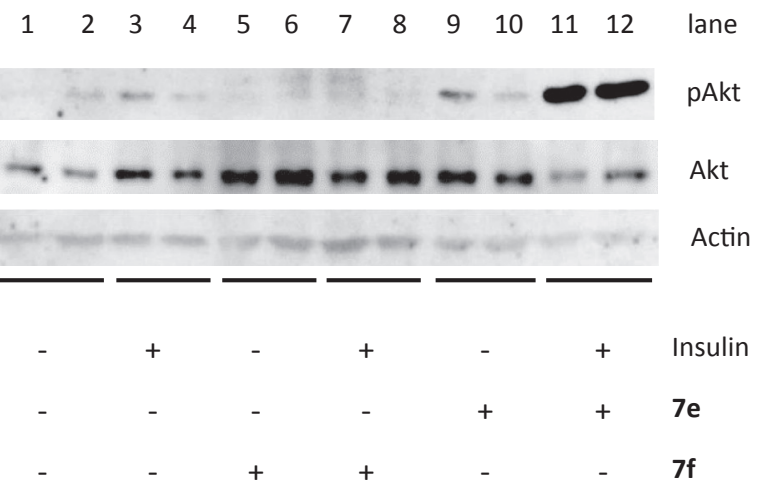

B

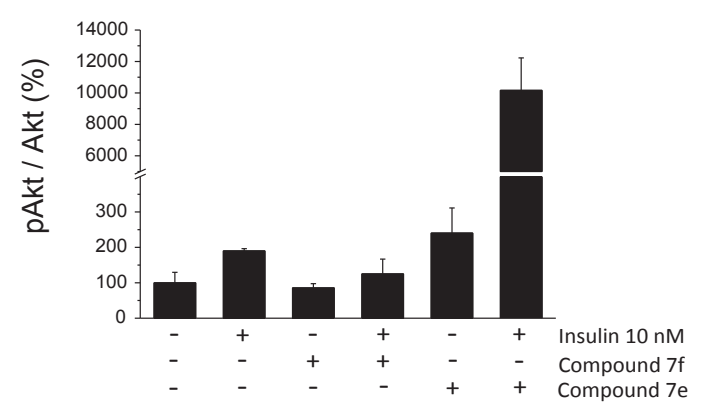

Fig. 9. Phosphorylation levels of Akt in human liver HepG2 cells treated with compounds 7e and 7f. HepG2 cells were starved for $20 \mathrm{~h}$, and incubated in the presence of $50 \mu \mathrm{M}$ of compounds $7 \mathrm{e}$ and $7 \mathrm{f}$ for $1 \mathrm{~h}$ at $37^{\circ} \mathrm{C}$. After, cells were stimulated with $10 \mathrm{nM}$ insulin, and then lysed to evaluate phosphorylation levels of Akt. (A), western blot; (B), quantification of western blot. Data reported in the fig. represent the mean values \pm S.E.

4.1.1.1. 3-(4-Fluorophenyl)-2-thioxo-4-imidazolidinone (8b). Yield 54\%; Rf 0.25; m.p. $227-230{ }^{\circ} \mathrm{C} ;{ }^{1} \mathrm{H}$ NMR (DMSO-d 6 ): $\delta 4.28\left(\mathrm{~s}, 2 \mathrm{H}, \mathrm{CH}_{2}\right.$ ); 7.32 (m, 2H, arom); 7.34 (m, 2H, arom); 10.46 (brs, $1 \mathrm{H}, \mathrm{NH}) .{ }^{13} \mathrm{C}$ NMR $\left(\mathrm{DMSO}-\mathrm{d}_{6}\right): \quad \delta \quad 49.7, \quad 116.2 \quad(\mathrm{~J}=23.25), \quad 130.3, \quad 131.6, \quad 162.3$ $(\mathrm{J}=243.75)$, 172.8, 183.8. Anal. $\left(\mathrm{C}_{9} \mathrm{H}_{7} \mathrm{FN}_{2} \mathrm{OS}\right)$ calcd: $\mathrm{C} 51.42 ; \mathrm{H}$ 3.36; N 13.33; found: C 51.74; H 3.51; N 13.17 .

4.1.1.2. 3-(4-Methoxyphenyl)-2-thioxo-4-imidazolidinone (8c). Yield 82\%; Rf 0.23; m.p. $222{ }^{\circ} \mathrm{C} ;{ }^{1} \mathrm{H}$ NMR (DMSO- $d_{6}$ ): 3.87 (s, $3 \mathrm{H}, \mathrm{OCH}_{3}$ ); 4.33 (s, 2H, $\left.\mathrm{CH}_{2}\right) ; 7.09$ (m, 2H, arom); 7.26 (m, 2H, arom); 10.40 (brs, $1 \mathrm{H}, \mathrm{NH}$ ). ${ }^{13} \mathrm{C}$ NMR (DMSO- $d_{6}$ ): $\delta 55.1,55.6,113.9,129.8,130.0,159.1$, 172.3, 183.7. Anal. $\left(\mathrm{C}_{10} \mathrm{H}_{10} \mathrm{~N}_{2} \mathrm{O}_{2} \mathrm{~S}\right)$ calcd: $\mathrm{C}$ 54.04; $\mathrm{H} 4.53 ; \mathrm{N}$ 12.60; found: C 53.89; $\mathrm{H} 4.44 ; \mathrm{N} 12.78$.

4.1.1.3. 3-(4-Thiomethylphenyl)-2-thioxo-4-imidazolidinone (8d). Yield $75 \%$; Rf 0.24; m.p. $232-235{ }^{\circ} \mathrm{C} ;{ }^{1} \mathrm{H}$ NMR (DMSO-d $d_{6}$ ): 2.32 (s, $3 \mathrm{H}$, $\mathrm{SCH}_{3}$ ); 4.28 (s, 2H, $\mathrm{CH}_{2}$ ); 6.53 (m, 2H, arom); 7.04 (m, 2H, arom); 9.93 (brs, $1 \mathrm{H}, \mathrm{NH}) .{ }^{13} \mathrm{C}$ NMR (DMSO-d $\left.d_{6}\right): \delta 15.9,55.0,122.0,130.5,135.9$, 139.1, 173.5, 182.5. Anal. $\left(\mathrm{C}_{10} \mathrm{H}_{10} \mathrm{~N}_{2} \mathrm{OS}_{2}\right)$ calcd: $\mathrm{C} 50.40 ; \mathrm{H} 4.23 ; \mathrm{N}$ 11.75; found: C 50.28; H 4.33; N 11.88.

4.1.2. General procedure for the synthesis of (5Z)-3-aryl-5-arylidene-2thioxo-4-imidazolidinones (7a-w)

A mixture of 3-aryl-2-thioxo-4-imidazolidinone $8(2.6 \mathrm{mmol})$, the appropriate arylaldehyde $(2.6 \mathrm{mmol})$ and piperidine $(2.1 \mathrm{mmol})$ in ethanol $(20 \mathrm{ml})$ was refluxed for $4-5 \mathrm{~h}$ until the reagent disappearance. The reaction mixture was cooled and poured into water acidified with $\mathrm{AcOH}$ (pH 3-4). The precipitate was separated by filtration, washed with water and dried. The crystallization from methanol of the crude product provided pure compounds 7 .

4.1.2.1. (5Z)-3-(4-Fluorophenyl)-5-(4-phenoxybenzylidene)-2-thioxo-4imidazolidinone (7a). Yield 54\%; Rf 0.85; $\mathrm{mp} 219-222{ }^{\circ} \mathrm{C} ;{ }^{1} \mathrm{H}$ NMR (DMSO- $d_{6}$ ): $\delta 6.69$ (s, $1 \mathrm{H}, \mathrm{CH}$ methylidene); 7.04 (m, 2H, arom); 7.11 (m, 2H, arom); 7.22 (m, 1H, arom); 7.35 (m, 2H, arom); 7.43-7.47 (m, 4H, arom); 7.85 (m, $2 \mathrm{H}$, arom). ${ }^{13} \mathrm{C}$ NMR (DMSO- $d_{6}$ ): $\delta 113.4,116.4$ $(J=23.9 \mathrm{~Hz}), 118.8,120.1,124.9,126.1,127.9,130.2,130.9,131.7$ $(J=8.8 \mathrm{~Hz}), 133.1,156.2,158.7,162.5(J=245.2 \mathrm{~Hz}), 164.5,178.8$. Anal. $\left(\mathrm{C}_{22} \mathrm{H}_{15} \mathrm{FN}_{2} \mathrm{O}_{2} \mathrm{~S}\right)$ calcd: $\mathrm{C} 67.68 ; \mathrm{H} 3.87 ; \mathrm{N} 7.18$; found: $\mathrm{C} 68.01 ; \mathrm{H}$ 3.99; N 6.98.

4.1.2.2. (5Z)-3-(4-Methoxyphenyl)-5-(4-phenoxybenzylidene)-2-thioxo-4imidazolidinone ( $7 \mathrm{~b})$. Yield $30 \%$; $\mathrm{Rf} 0.73$; $\mathrm{mp} 227-230{ }^{\circ} \mathrm{C} ;{ }^{1} \mathrm{H}$ NMR (DMSO- $d_{6}$ ): $\delta 3.80\left(\mathrm{~s}, 3 \mathrm{H}, \mathrm{OCH}_{3}\right) ; 6.67$ (s, $1 \mathrm{H}, \mathrm{CH}$ methylidene); 7.04 (m, 4H, arom); 7.10 (m, 2H, arom); $7.22(\mathrm{~m}, 1 \mathrm{H}$, arom); $7.26(\mathrm{~m}, 2 \mathrm{H}$, arom); 7.45 (m, 2H, arom); 7.85 (m, $2 \mathrm{H}$, arom). ${ }^{13} \mathrm{C}$ NMR (DMSO- $\left.d_{6}\right): \delta$ 55.4, 112.4, 114.0, 118.1, 119.4, 124.3, 125.5, 125.8, 127.4, 129.9, $130.3,132.4$, 155.6, 158.0, 159.3, 164.1, 178.8. Anal. $\left(\mathrm{C}_{23} \mathrm{H}_{18} \mathrm{~N}_{2} \mathrm{O}_{3} \mathrm{~S}\right)$ calcd: C 68.64; H 4.51; N 6.96; found: C 68.50; H 4.27; N 7.14.

4.1.2.3. (5Z)-3-(4-Methylthiophenyl)-5-(4-phenoxybenzylidene)-2-thioxo4-imidazolidinone (7c). Yield 63\%; Rf 0.77; mp 239-242 ${ }^{\circ} \mathrm{C} ;{ }^{1} \mathrm{H}$ NMR (DMSO- $d_{6}$ ): $\delta 2.53$ (s, 3H, $\mathrm{SCH}_{3}$ ); 6.68 (s, $1 \mathrm{H}, \mathrm{CH}$ methylidene); 7.03 (m, 2H, arom); 7.10 (m, 2H, arom); 7.22 (m, 1H, arom); 7.29-7.39 (m, $4 \mathrm{H}$, arom); 7.45 (m, 2H, arom); 7.85 (m, 2H, arom). ${ }^{13} \mathrm{C}$ NMR (DMSO-d ${ }_{6}$ ): $\delta 15.1,113.0,118.6,119.9,125.9,126.5,127.8,129.4$, 129.9, 130.4, 131.0, 132.7, 139.8, 151.3, 158.5, 164.3, 178.8. Anal. $\left(\mathrm{C}_{23} \mathrm{H}_{18} \mathrm{~N}_{2} \mathrm{O}_{2} \mathrm{~S}_{2}\right)$ calcd: C 66.00; H 4.33; N 6.69; found: C 66.19; H 4.18; N 6.88 .

4.1.2.4. (5Z)-3-Phenyl-5-(4-phenylbenzylidene)-2-thioxo-4imidazolidinone (7e). (CAS 740814-34-0) Yield 60\%; Rf 0.78; mp 273-275 ${ }^{\circ} \mathrm{C}$; ${ }^{1} \mathrm{H}$ NMR (DMSO- $d_{6}$ ): $\delta 6.69$ (s, $1 \mathrm{H}, \mathrm{CH}$ methylidene); 7.35-7.40 (m, 2H, arom); 7.46-7.53 (m, 3H, arom); 7.74-7.78 (m, 5H, arom); 7.93 (m, 2H, arom); 8.16 (m, $2 \mathrm{H}$, arom); 12.67 (brs, $1 \mathrm{H}, \mathrm{NH})$. ${ }^{13}$ C NMR (DMSO- $d_{6}$ ): $\delta 112.6,126.3,126.8,127.0,128.1,128.9,129.1$, 131.1, 131.5, 133.3, 139.2, 140.9, 164.0, 178.6. Anal. $\left(\mathrm{C}_{22} \mathrm{H}_{16} \mathrm{~N}_{2} \mathrm{OS}\right)$ calcd: C 74.13; H 4.52; N 7.86; found: C 73.97; H 4.38; N 7.98.

4.1.2.5. (5Z)-5-(3-Benzyloxybenzylidene)-3-phenyl-2-thioxo-4imidazolidinone (7h). Yield 57\%; Rf 0.80; mp $197-200{ }^{\circ} \mathrm{C} ;{ }^{1} \mathrm{H}$ NMR (DMSO- $\left.d_{6}\right): \delta 5.19$ (s, 2H, OCH $\left.{ }_{2}\right), 6.65$ (s, $1 \mathrm{H}, \mathrm{CH}$ methylidene); 7.09 (m, $1 \mathrm{H}$, arom); 7.38-7.53 (m, $13 \mathrm{H}$, arom). ${ }^{13} \mathrm{C}$ NMR (DMSO- $d_{6}$ ): $\delta 69.5$, 113.0, 116.3, 116.4, 123.30, 126.7, 128.0, 128.1, 128.7, 128.9, 129.1, 130.2, 133.4, 133.7, 137.0, 158.8, 164.1, 178.9. Anal. $\left(\mathrm{C}_{23} \mathrm{H}_{18} \mathrm{~N}_{2} \mathrm{O}_{2} \mathrm{~S}\right)$ calcd: C 71.48; H 4.69; N 7.25; found: C 71.65; H 4.84; N 7.03.

4.1.2.6. (5Z)-5-(4-Benzyloxybenzylidene)-3-phenyl-2-thioxo-4 imidazolidinone (7i). (CAS 469896-60-4) Yield 56\%; Rf 0.75; mp 233-235 ${ }^{\circ} \mathrm{C}$; ${ }^{1} \mathrm{H}$ NMR (DMSO-d $d_{6}$ ): $\delta 5.19\left(\mathrm{~s}, 2 \mathrm{H}, \mathrm{OCH}_{2}\right.$ ), $6.67(\mathrm{~s}, 1 \mathrm{H}$, CH methylidene); 7.10 (m, 2H, arom); 7.39-7.49 (m, 10H, arom); 7.82 (m, 2H, arom); 12.51 (brs, $1 \mathrm{H}, \mathrm{NH}$ ). ${ }^{13} \mathrm{C}$ NMR (DMSO- $d_{6}$ ): $\delta 69.4,113.5$, 115.3, 124.5, 125.1, 127.9, 128.0, 128.5, 128.9, 132.4, 133.4, 136.7, 159.5, 164.0, 178.0. Anal. $\left(\mathrm{C}_{23} \mathrm{H}_{18} \mathrm{~N}_{2} \mathrm{O}_{2} \mathrm{~S}\right)$ calcd: C 71.48; $\mathrm{H}$ 4.69; $\mathrm{N}$ 7.25; found: C 71.73; H 4.89; N 7.12.

4.1.2.7. (5Z)-5-(3-Trifluoromethoxybenzylidene)-3-phenyl-2-thioxo-4imidazolidinone (7m). Yield 38\%; Rf 0.76; $\mathrm{mp} 140-143{ }^{\circ} \mathrm{C} ;{ }^{1} \mathrm{H}$ NMR (DMSO- $d_{6}$ ): $\delta 6.71$ (s, $1 \mathrm{H}, \mathrm{CH}$ methylidene); $7.36-7.39$ (m, 3H, arom); 7.44-7.47 (m, 1H, arom), 7.49-7.52 (m, 2H, arom), 7.54-7.58 (m, 1H, arom), $7.79-7.81\left(\mathrm{~m}, 1 \mathrm{H}\right.$, arom), $7.84\left(\mathrm{~s}, 1 \mathrm{H}\right.$, arom) ${ }^{13} \mathrm{C}$ NMR 
(DMSO- $\left.d_{6}\right)$ : $\delta 111.1,120.7(J=256.6 \mathrm{~Hz}), 122.0,122.9,128.0,129.3$, $129.4,130.0,131.2,133.7,135.2,149.3,164.4,179.5$. Anal. $\left(\mathrm{C}_{17} \mathrm{H}_{11} \mathrm{~F}_{3} \mathrm{~N}_{2} \mathrm{O}_{2} \mathrm{~S}\right)$ calcd: C 56.04; $\mathrm{H} 3.04 ; \mathrm{N} 7.69$; found: C $55.81 ; \mathrm{H}$ 2.79; N 7.92 .

4.1.2.8. (5Z)-5-(4-Trifluoromethylthiobenzylidene)-3-phenyl-2-thioxo-4imidazolidinone (7n). Yield 25\%; Rf 0.87; mp $186-189^{\circ} \mathrm{C} ;{ }^{1} \mathrm{H}$ NMR (DMSO- $d_{6}$ ): $\delta 6.69$ (s, $1 \mathrm{H}, \mathrm{CH}$ methylidene); 7.37 (m, 2H, arom); 7.48-7.51 (m, 3H, arom); 7.75 (m, 2H, arom), 7.91 (m, 2H, arom), 12.70 (brs, $1 \mathrm{H}, \mathrm{NH}$ ). ${ }^{13} \mathrm{C}$ NMR (DMSO- $d_{6}$ ): $\delta 110.9,123.9,128.5,129.2$, $129.3,130.0(J=309.3 \mathrm{~Hz}), 131.7,133.6,135.8,136.6,164.2$, 179.7. Anal. $\left(\mathrm{C}_{17} \mathrm{H}_{11} \mathrm{~F}_{3} \mathrm{~N}_{2} \mathrm{OS}_{2}\right)$ calcd: C 53.68; $\mathrm{H} 2.91$; N 7.36; found: C 53.95; H 3.06; N 7.52.

4.1.2.9. (5Z)-5-(3,4-Dihydroxybenzylidene)-3-phenyl-2-thioxo-4imidazolidinone (7p). (CAS 897340-70-4) Yield 21\%; Rf 0.13; mp 186-189 ${ }^{\circ} \mathrm{C} ;{ }^{1} \mathrm{H}$ NMR (DMSO- $d_{6}$ ): $\delta 6.53$ (s, $1 \mathrm{H}, \mathrm{CH}$ methylidene), 6.80 (s, 1H, arom), 7.17-7.21 (m, 2H, arom); 7.33-7.36 (m, 2H, arom), 7.43-7.52 (m, 3H, arom); 9.20 and 9.79 (2 brs, $2 \mathrm{H}, \mathrm{OH}) ; 12.40$ (s br, $1 \mathrm{H}, \mathrm{NH}) .{ }^{13} \mathrm{C}$ NMR (DMSO- $d_{6}$ ): $\delta 115.4,116.5,118.5,123.9,124.3$, 124.4, 129.2, 129.3, 129.4, 134.0, 146.0, 148.5, 164.4, 178.3. Anal. $\left(\mathrm{C}_{16} \mathrm{H}_{12} \mathrm{~N}_{2} \mathrm{O}_{3} \mathrm{~S}\right)$ calcd: $\mathrm{C}$ 61.53; H 3.87; N 8.97; found: C 61.78; H 3.64; N 9.09 .

4.1.2.10. (5Z)-5-(3,4,5-Trimethoxybenzylidene)-3-phenyl-2-thioxo-4imidazolidinone (7s). (CAS 94452-09-2) Yield 59\%; Rf 0.39; mp $186-189{ }^{\circ} \mathrm{C} ;{ }^{1} \mathrm{H}$ NMR (DMSO- $\left.d_{6}\right): \delta 3.70\left(\mathrm{~s}, 3 \mathrm{H}, \mathrm{OCH}_{3}\right.$ ), $3.86(\mathrm{~s}, 6 \mathrm{H}$, $\mathrm{OCH}_{3}$ ), 6.63 (s, $1 \mathrm{H}, \mathrm{CH}$ methylidene), 7.03 (s, 2H, arom), 7.35-7.37 (m, 2H, arom); 7.44-7.47 (m, 1H, arom), 7.49-7.52 (m, 2H, arom); 12.66 (brs, $1 \mathrm{H}, \mathrm{NH}$ ). ${ }^{13} \mathrm{C}$ NMR (DMSO- $\left.d_{6}\right): \delta 56.3,60.2,108.1,113.8,125.6$, $127.9,128.9,133.4,139.0,153.1,164.0$, 178.5. Anal. $\left(\mathrm{C}_{19} \mathrm{H}_{18} \mathrm{~N}_{2} \mathrm{O}_{4} \mathrm{~S}\right)$ calcd: C 66.61; H 4.90; N 7.56; found: C 66.90; H 5.11; N 7.68.

4.1.2.11. (5Z)-5-(4-Fluoro-3-methoxybenzylidene)-3-phenyl-2-thioxo-4imidazolidinone (7t). Yield 55\%; Rf 0.73 ; $\mathrm{mp} 217-220{ }^{\circ} \mathrm{C} ;{ }^{1} \mathrm{H}$ NMR (DMSO- $\left.d_{6}\right): \delta 3.94\left(\mathrm{~s}, 3 \mathrm{H}, \mathrm{OCH}_{3}\right) ; 6.68(\mathrm{~s}, 1 \mathrm{H}, \mathrm{CH}$ methylidene); 7.27-7.55 (3m, 8H, arom). ${ }^{13} \mathrm{C}$ NMR (DMSO- $d_{6}$ ): $\delta 56.4,112.4$, 115.7, 116.4, 116.5, 123.7, 126.5, 128.9, 129.0, 129.6, 133.4, 147.5, 151.2, 153.2, 164.1, 178.8. Anal. $\left(\mathrm{C}_{17} \mathrm{H}_{13} \mathrm{FN}_{2} \mathrm{O}_{2} \mathrm{~S}\right)$ calcd: $\mathrm{C} 62.18 ; \mathrm{H}$ 3.99; N 8.53; found: C 61.95; H 3.87; N 8.69.

4.1.2.12. (5Z)-5-(4-Acetylaminobenzylidene)-3-phenyl-2-thioxo-4imidazolidinone (7u). (CAS 41534-94-5) Yield 51\%; Rf 0.05; mp $277-280{ }^{\circ} \mathrm{C} ;{ }^{1} \mathrm{H}$ NMR (DMSO- $d_{6}$ ): $\delta 2.06\left(\mathrm{~s}, 3 \mathrm{H}, \mathrm{CH}_{3}\right), 6.62(\mathrm{~s}, 1 \mathrm{H}, \mathrm{CH}$ methylidene); 7.37 (m, $2 \mathrm{H}$, arom), 7.49 (m, $2 \mathrm{H}$, arom), 7.65 (m, $2 \mathrm{H}$, arom), 7.77 (m, 2H, arom), 10.17 (brs, $1 \mathrm{H}, \mathrm{NH}), 12.49$ (brs, $1 \mathrm{H}, \mathrm{NH}$ ). ${ }^{13}$ C NMR (DMSO- $d_{6}$ ): $\delta 20.6,101.5,118.9,125.4,127.3,128.9,129.6$, 129.7, 131.5, 141.0, 164.4, 169.2, 178.6. Anal. $\left(\mathrm{C}_{18} \mathrm{H}_{15} \mathrm{~N}_{3} \mathrm{O}_{2} \mathrm{~S}\right)$ calcd: $\mathrm{C}$ 64.08; H 4.48; N 12.45; found: C 64.21; H 4.36; N 12.63 .

4.1.2.13. (5Z)-5-(Naphtalen-1-ylmethylidene)-3-phenyl-2-thioxo-4imidazolidinone (7v). (CAS 61442-32-8) Yield 72\%; Rf 0.82; mp 108-110 ${ }^{\circ} \mathrm{C} ;{ }^{1} \mathrm{H}$ NMR (DMSO- $d_{6}$ ): $\delta 7.23$ (s, $1 \mathrm{H}, \mathrm{CH}$ methylidene); 7.37-7.61 (m, 8H, arom); 7.86 (m, 1H, arom); 7.97 (m, 2H, arom); 8.10 (m, $1 \mathrm{H}$, arom). ${ }^{13} \mathrm{C}$ NMR (DMSO- $d_{6}$ ): $\delta 109.5,123.8,125.9,126.5$, 127.2, 128.6, 128.8, 128.9, 129.0, 129.7, 131.2, 133.4, 163.6, 178.8 . Anal. $\left(\mathrm{C}_{20} \mathrm{H}_{14} \mathrm{~N}_{2} \mathrm{OS}\right)$ calcd: C $72.70 ; \mathrm{H} 4.27$; $\mathrm{N}$ 8.48; found: $\mathrm{C} 72.93 ; \mathrm{H}$ $4.50 ; \mathrm{N} 8.31$.

4.1.2.14. (5Z)-5-(Naphtalen-2-ylmethylidene)-3-phenyl-2-thioxo-4 imidazolidinone (7w). (CAS 61442-35-1) Yield 52\%; Rf 0.82; mp $210-213{ }^{\circ} \mathrm{C} ;{ }^{1} \mathrm{H}$ NMR (DMSO- $d_{6}$ ): $\delta 6.80$ (s, $1 \mathrm{H}, \mathrm{CH}$ methylidene); 7.36-7.57 (m, 10H, arom); 7.83-7.98 (m, 2H, arom); 12.74 (brs, $1 \mathrm{H}$,
NH). ${ }^{13} \mathrm{C}$ NMR (DMSO- $d_{6}$ ): $\delta 113.0,126.7,126.8,127.4,127.5,127.7$, 128.4, 128.6, 128.9, 129.0, 130.0, 130.1, 133.0, 133.1, 133.4, 164.0, 178.9. Anal. $\left(\mathrm{C}_{20} \mathrm{H}_{14} \mathrm{~N}_{2} \mathrm{OS}\right)$ calcd: $\mathrm{C} 72.70 ; \mathrm{H} 4.27$; $\mathrm{N} \mathrm{8.48}$; found: $\mathrm{C}$ 72.51; H 4.09; N 8.60.

\subsection{Docking studies}

In order to clarify the preferred inhibition mode and binding interactions of the tested 5-arylidene-2-thioxo-4-imidazolidinones 7 , compounds $7 \mathrm{f}, 7 \mathrm{~g}-\mathrm{i}, \mathbf{7 1}, \mathbf{7 o}, \mathbf{7 r}, \mathbf{7 v}$, and $\mathbf{7 w}$ were docked into a crystal structure of PTP1B (PDB code 2VEV) [50].

Docking was performed with the software GOLD [51] version 5.2 allowing binding to the whole protein surface. The protein and ligand structures were prepared prior to docking using MOE [52] 2015.10. For each ligand 25 poses were generated and analyzed after energy minimization of the ligand in the respective pose together with the surrounding protein residues with MOE using the Amber12:EHT forcefield. 3D representations were generated with MOE.

\subsection{Biology}

\subsubsection{Expression and purification of recombinant human PTP1B}

Recombinant, human PTP1B enzyme was expressed as fusion protein in E. coli and purified as previously described [37]. Briefly, E. coli TB1 strain was transformed with pGEX-2T bacterial expression vector harbouring the complete sequence of PTP1B cloned downstream the Glutathione-S-Transferase (GST) sequence. Transformed bacteria were grown until 0.8 O.D. and then stimulated for two hours with $0.1 \mathrm{mM}$ isopropyl-thiogalactoside (IPTG) to induce expression of fusion protein (GST-PTP1B). Then, bacteria were collected by centrifugation and stored at $-20^{\circ} \mathrm{C}$. The fusion protein was purified from bacterial lysate by affinity chromatography, using a column loaded with glutathioneagarose resin. After elution from column, fractions containing fusion protein were collected, concentrated and incubated with 5 U.I. of bovine thrombin (Sigma Aldrich T7513) for $3 \mathrm{~h}$ at $37^{\circ} \mathrm{C}$. Finally, PTP1B was purified from GST and thrombin by gel filtration using a Superdex G75 column. The enzyme purity of purified protein was determined by SDS-PAGE.

\subsubsection{Enzymatic assays}

The assays were carried out at $37^{\circ} \mathrm{C}$ in $0.075 \mathrm{M} \beta$, $\beta$-dimethylglutaric acid buffer pH 7.0 containing $1 \mathrm{mM}$ EDTA and $0.1 \mathrm{mM}$ DTT. The $p$ nitrophenylphosphate ( $p$-NPP) was used as substrate; the final volume of tests was $1 \mathrm{ml}$. Reactions were started by diluting an aliquot of enzyme in the assay solution, and stopped after an appropriate time diluting reaction solution with $2 \mathrm{ml}$ of $0.1 \mathrm{M} \mathrm{KOH}$. The amount of $p$-NPP released was determined using a spectrophotometer, reading the absorbance of solutions at $400 \mathrm{~nm}\left(\varepsilon=18000 \mathrm{M}^{-1} \mathrm{~cm}^{-1}\right)$.

Preliminary screening and the $\mathrm{IC}_{50}$ values were both carried out using a fixed substrate concentration $(2.5 \mathrm{mM})$ corresponding to the $\mathrm{Km}$ value of PTP1B. The IC $_{50}$ values were determined measuring residual activity of enzyme in the presence of increasing inhibitor concentration. All tests were carried out in triplicate. Data obtained were fitted using the following equation:

$$
\frac{\boldsymbol{V i}}{\boldsymbol{V} 0}=\frac{\boldsymbol{M a x}-\operatorname{Min}}{1+\left(\frac{x}{I C_{50}}\right)^{\text {slope }}}
$$

where $\mathrm{V}_{\mathrm{i}}$ is the activity measured in the presence of the inhibitor, $\mathrm{V}_{0}$ the activity of enzyme measured in the absence of inhibitor, and " $x$ " is the concentration of inhibitor.

Dilution assays were carried out to evaluate the action mechanism of inhibitors [37]. The enzyme was incubated in the presence of 
saturating amount of each inhibitor for $1 \mathrm{~h}$ at $37^{\circ} \mathrm{C}$. Then, aliquot of samples was diluted 400 folds in the assay buffer to evaluate residual enzyme activity.

The kinetic parameters, $\mathrm{Km}$ and Vmax, were determined measuring the initial hydrolysis rates in the presence of increasing substrate concentrations. Data obtained were fitted using the Michaelis-Menten equation. The effects of inhibitors on both $\mathrm{Km}$ and Vmax was determined analysing the effects of increasing inhibitor concentrations on substrate hydrolysis rate. Finally, the inhibition constant (Ki) was determined using the appropriate equations, depending from the inhibition mechanism.

\subsubsection{Ex vivo assay}

Ex vivo tests were carried out using human liver HepG2 cells obtained from the American Type Culture Collection (ATCC).

The effects of inhibitors on cell viability was evaluated by using MTT assay. HepG2 liver cells were plated in 24 well plates and incubated in the presence of $50 \mu \mathrm{M}$ inhibitors for $24 \mathrm{~h}$. After, cells were incubated in the presence of $0.5 \mathrm{mg} / \mathrm{ml}$ MTT solution for $1 \mathrm{~h}$ and after washed with PBS. Then, $300 \mu$ of DMSO was added to each well to solubilize formazane salts. Cells viability was evaluated measuring the absorbance of solution at $570 \mathrm{~nm}$. Data obtained were normalized respect to control test, which was carried out incubating liver cells with an equivalent amount of DMSO, the solvent used to dissolve each compound.

The effects on compounds on insulin signalling pathway was analysed using a different protocol. Briefly, HepG2 liver cells were plated in P35 dishes and grown until 70\% confluence and then incubated in the presence of starvation medium for $20 \mathrm{~h}$. After this interval time, cells were incubated in the presence of $50 \mu \mathrm{M}$ inhibitors for $60 \mathrm{~min}$ at $37^{\circ} \mathrm{C}$ and then stimulated or not with $10 \mathrm{nM}$ insulin for $15 \mathrm{~min}$. Control experiment was carried out incubating cells in the presence of $10 \mathrm{nM}$ insulin alone. After treatment, cells were lysed, separated by SDS-PAGE, and transferred onto PVDF membrane by western blot method. Phosphorylation levels of Akt was evaluated by using specific antibodies (Santa Cruz Biotechnology); data obtained were normalized respect to total Akt levels.

\section{Acknowledgements}

This work was supported by University of Messina and University of Florence.

\section{Appendix A. Supplementary material}

Supplementary data to this article can be found online at https:// doi.org/10.1016/j.bioorg.2019.103211.

\section{References}

[1] J. Bakke, F.G. Haj, Protein tyrosine phosphatase 1B substrates and metabolic regulation, Semin. Cell. Dev. Biol. 37 (2015) 58-65, https://doi.org/10.1016/j. semcdb.2014.09.020.

[2] Z.Y. Zhang, G.T. Dodd, T. Tiganis, Protein tyrosine phosphatases in hypothalamic insulin and leptin signalling, Trends Pharmacol. Sci. 36 (2015) 661-674, https:// doi.org/10.1016/j.tips.2015.07.003.

[3] J.M. Zabolotny, K.K. Bence-Hanulec, A. Stricker-Krongrad, F. Haj, Y. Wang, Y. Minokoshi, Y.B. Kim, J.K. Elmquist, L.A. Tartaglia, B.B. Kahn, B.G. Neel, PTP1B regulates leptin signal transduction in vivo, Dev. Cell. 2 (2002) 489-495, https:// doi.org/10.1016/S1534-5807(02)00148-X.

[4] A. Cheng, N. Uetani, P.D. Simoncic, V.P. Chaubey, A. Lee-Loy, C.J. McGlade, B.P. Kennedy, M.L. Tremblay, Attenuation of leptin action and regulation of obesity by protein tyrosine phosphatase 1B, Dev. Cell. 2 (2002) 497-503, https://doi.org/ 10.1016/S1534-5807(02)00149-1.

[5] R. Di Paola, L. Frittitta, G. Miscio, M. Bozzali, R. Baratta, M. Centra, D. Spampinato, M.G. Santagati, T. Ercolino, C. Cisternino, T. Soccio, S. Mastroianno, V. Tassi, P. Almgren, A. Pizzuti, R. Vigneri, V. Trischitta, A variation in 3' UTR of hPTP1B increases specific gene expression and associates with insulin resistance, Am. J. Hum. Genet. 20 (2002) 70806-70812, https://doi.org/10.1086/339270.

[6] J.M. Zabolotny, F.G. Haj, Y.B. Kim, H.J. Kim, G.I. Shulman, J.K. Kim, B.G. Neel,
B.B. Kahn, Transgenic overexpression of protein-tyrosine phosphatase 1B in muscle causes insulin resistance, but overexpression with leukocyte antigen-related phosphatase does not additively impair insulin action, J. Biol. Chem. 279 (2004) 24844-24851, https://doi.org/10.1074/jbc.M310688200.

[7] C.L. White, A. Whittington, M.J. Barnes, Z. Wang, G.A. Bray, C.D. Morrison, HF diets increase hypothalamic PTP1B and induce leptin resistance through both leptin-dependent and independent mechanisms, Am. J. Physiol. Endocrinol Metab. 296 (2009) E291-E299, https://doi.org/10.1152/ajpendo.90513.2008.

[8] M. Elchebly, P. Payette, E. Michaliszyn, W. Cromlish, S. Collins, A.L. Loy, D. Normandin, A. Cheng, J. Himms-Hagen, C.C. Chan, C. Ramachandran, M.J. Gresser, M.L. Tremblay, B.P. Kennedy, Increased insulin sensitivity and obesity resistance in mice lacking the protein tyrosine phosphatase-1B gene, Science 283 (1999) 1544-1548, https://doi.org/10.1126/science.283.5407.1544.

[9] L.D. Klaman, O. Boss, O.D. Peroni, J.K. Kim, J.L. Martino, J.M. Zabolotny, N. Moghal, M. Lubkin, Y.B. Kim, A.H. Sharpe, A. Stricker-Krongrad, G.I. Shulman, B.G. Neel, B.B. Kahn, Increased energy expenditure, decreased adiposity, and tissuespecific insulin sensitivity in protein-tyrosine phosphatase 1B-deficient mice, Mol. Cell. Biol. 20 (2000) 5479-5489, https://doi.org/10.1128/MCB.20.15.5479-5489. 2000.

[10] R.C. Tsou, K.S. Rak, D.J. Zimmer, K.K. Bence, Improved metabolic phenotype of hypothalamic PTP1B-deficiency is dependent upon the leptin receptor, Mol. Metab. 3 (2014) 301-312, https://doi.org/10.1016/j.molmet.2014.01.008.

[11] M. Delibegovic, K.K. Bence, N. Mody, E.G. Hong, H.J. Ko, J.K. Kim, B.B. Kahn, B.G. Neel, Improved glucose homeostasis in mice with muscle-specific deletion of protein-tyrosine phosphatase 1B, Mol. Cell. Biol. 27 (2007) 7727-7734, https://doi. org /10.1128/MCB.00959-07.

[12] K.K. Bence, M. Delibegovic, B. Xue, C.Z. Gorgun, G.S. Hotamisligil, B.G. Neel, B.B. Kahn, Neuronal PTP1B regulates body weight, adiposity and leptin action, Nat. Med. 12 (2006) 917-924, https://doi.org/10.1038/nm1435.

[13] J.M. Zabolotny, Y.B. Kim, L.A. Welsh, E.E. Kershaw, B.G. Neel, B.B. Kahn, Proteintyrosine phosphatase 1B expression is induced by inflammation in vivo, J. Biol. Chem. 283 (2008) 14230-14241, https://doi.org/10.1074/jbc.M800061200.

[14] N. Esser, S. Legrand-Poels, J. Piette, A.J. Scheen, N. Paquot, Inflammation as a link between obesity, metabolic syndrome and type 2 diabetes, Diabetes Res. Clin. Pract. 105 (2014) 141-150, https://doi.org/10.1016/j.diabres.2014.04.006.

[15] G.J. Song, M. Jung, J.H. Kim, H. Park, M.H. Rahman, S. Zhang, Z.Y. Zhang, D.H. Park, H. Kook, I.K. Lee, K. Suk, A novel role for protein tyrosine phosphatase $1 \mathrm{~B}$ as a positive regulator of neuroinflammation, J. Neuroinflamm. 13 (2016) 86 https://doi.org/101186/s12974-016-0545-3.

[16] Y.M. Jeon, S. Lee, S. Kim, Y. Kwon, K. Kim, C.G. Chung, S. Lee, S.B. Lee, H.J. Kim, Neuroprotective effects of protein tyrosine phosphatase 1B inhibition against ER stress-induced toxicity, Mol. Cells. 40 (2017) 280-290, https://doi.org/10.14348/ molcells.2017.2320.

[17] Suzanne M. De La Monte, Insulin resistance and Alzheimer's disease, BMB Rep. 42 (8) (2009) 475-481, https://doi.org/10.5483/BMBRep.2009.42.8.475.

[18] D. Bosco, A. Fava, M. Plastino, T. Montalcini, A. Pujia, Possible implications of insulin resistance and glucose metabolism in Alzheimer's disease pathogenesis, J. Cell. Mol. Med. 15 (2011) 1807-1821, https://doi.org/10.1111/j.1582-4934.2011. 01318.x.

[19] M.N.N. Vieira, N.M. Lyra e Silva, S.T. Ferreira, F.G. De Felice, Protein tyrosine phosphatase 1B (PTP1B): a potential target for Alzheimer's therapy? Front. Aging Neurosci. 9 (2017) 7. https://doi.org/103389/fnagi201700007.

[20] S.G. Julien, N. Dubè, M. Read, J. Penney, M. Paquet, Y. Han, B.P. Kennedy, W.J. Muller, M.L. Tremblay, Protein tyrosine phosphatase 1B deficiency or inhibition delays ErbB2-induced mammary tumorigenesis and protect from lung metastasis, Nat. Genet. 39 (2007) 338-346, https://doi.org/10.1038/ng1963.

[21] N. Wang, J. She, W. Liu, J. Shi, Q. Yang, B. Shi, P. Hou, Frequent amplification of PTP1B is associated with poor survival of gastric cancer patients, Cell Cycle 14 (2015) 732-743, https://doi.org/10.1080/15384101.2014.998047.

[22] H. Liu, Y. Wu, S. Zhu, W. Liang, Z. Wang, Y. Wang, T. Lv, Y. Yao, D. Yuan, Y. Song, PTP1B promotes cell proliferation and metastasis through activating src and ERK1/ 2 in non-small cell lung cancer, Cancer Lett. 359 (2015) 218-225, https://doi.org/ 10.1016/j.canlet.2015.01.020

[23] E. Hoekstra, A.M. Das, M. Swets, W. Cao, C.J. van der Woude, M.J. Bruno, M.P. Peppelenbosch, P.J.K. Kuppen, T.L.M. ten Hagen, G.M. Fuhler, Increased PTP1B expression and phosphatase activity in colorectal cancer results in a more invasive phenotype and worse patient outcome, Oncotarget 7 (2016) 21922-21938 https://dx.doi.org/10.18632\%2Foncotarget.7829.

[24] S. Zhu, J.D. Bjorge, D.J. Fujita, PTP1B contributes to the oncogenic properties of colon cancer cells through Src activation, Cancer Res. 67 (2007) 10129-10137, https://doi.org/10.1158/0008-5472.CAN-06-4338.

[25] L. Bialy, H. Waldmann, Inhibitors of protein tyrosine phosphatases: next-generation drugs? Angew. Chem. Int. Ed. 44 (2005) 3814-3839, https://doi.org/10.1002/anie. 200461517.

[26] A.J. Nichols, R.D. Mashal, B. Balkan, Toward the discovery of small molecule PTP1B inhibitors for the treatment of metabolic diseases, Drug Dev. Res. 67 (2006) 559-566, https://doi.org/10.1002/ddr.20122.

[27] S. Zhang, Z.Y. Zhang, PTP1B as a drug target: recent developments in PTP1B inhibitor discovery, Drug Discov. Today. 12 (2007) 373-381, https://doi.org/10. 1016/j.drudis.2007.03.011.

[28] A.P. Combs, Recent advances in the discovery of competitive protein tyrosine phosphatase 1B inhibitors for the treatment of diabetes, obesity and cancer, J. Med. Chem. 53 (2010) 2333-2344, https://doi.org/10.1021/jm901090b.

[29] D. Popov, Novel protein tyrosine phosphatase 1B inhibitors: interaction requirements for improved intracellular efficacy in type 2 diabetes mellitus and obesity control, Biochem. Biophys. Res. Commun. 410 (2011) 377-381, https://doi.org/10. 
1016/j.bbrc.2011.06.009

[30] S. Thareja, S. Aggarwal, T.R. Bhardwaj, M. Kumar, Protein tyrosine phosphatase 1B inhibitors: a molecular level legitimate approach for the management of diabetes mellitus, Med. Res. Rev. 32 (2012) 459-517, https://doi.org/10.1002/med.20219.

[31] Y.A. Puius, Y. Zhao, M. Sullivan, D.S. Lawrence, S.C. Almo, Z.Y. Zhang, Identification of a second aryl phosphate-binding site in protein-tyrosine phosphatase 1B: a paradigm for inhibitor design, Proc. Natl. Acad. Sci. USA 94 (1997) 13420-13425, https://doi.org/10.1073/pnas.94.25.13420.

[32] G. Scapin, S.B. Patel, J.W. Becker, Q. Wang, C. Desponts, D. Waddleton, K. Skorey, W. Cromlish, C. Bayly, M. Therien, J.Y. Gauthier, C.S. Li, C.K. Lau, C. Ramachandran, B.P. Kennedy, E. Asante-Appiah, The structural basis for the selectivity of benzotriazole inhibitors of PTP1B, Biochemistry 42 (2003) 11451-11459, https://doi.org/10.1021/bi035098j.

[33] M.S. Choy, Y. Li, L.E.S.F. Machado, M.B.A. Kunze, C.R. Connors, X. Wei, K. LindorffLarsen, R. Page, W. Peti, Conformational rigidity and protein dynamics at distinct timescales regulate PTP1B activity and allostery, Mol. Cell. 65 (2017) 644-658, https://doi.org/10.1016/j.molcel.2017.01.014.

[34] C. Wiesmann, K.J. Barr, J. Kung, J. Zhu, D.A. Erlanson, W. Shen, B.J. Fahr, M. Zhong, L. Taylor, M. Randal, R.S. McDowell, S.K. Hansen, Allosteric inhibition of protein tyrosine phosphatase 1B, Nat. Struct. Mol. Biol. 11 (2004) 730-737, https:// doi.org/10.1038/nsmb803.

[35] N. Krishnan, D. Koveal, D.H. Miller, B. Xue, S.D. Akshinthala, J. Kragelj, M.R. Jensen, C.M. Gauss, R. Page, M. Blackledge, S.K. Muthuswamy, W. Peti, N.K. Tonks, Targeting the disordered C terminus of PTP1B with an allosteric inhibitor, Nat. Chem. Biol. 10 (2014) 558-566 https://dx.doi.org/ 10.1038\%2Fnchembio.1528.

[36] K.A. Lantz, S.G. Emeigh Hart, S.L. Planey, M.F. Roitman, I.A. Ruiz-White, H.R. Wolfe, M.P. McLane, Inhibition of PTP1B by Trodusquemine (MSI-1436) causes fat-specific weight loss in diet-induced obese mice, Obesity 18 (2010) 1516-1523, https://doi.org/10.1038/oby.2009.444.

[37] R. Ottanà, P. Paoli, A. Naß, G. Lori, V. Cardile, I. Adornato, A. Rotondo, A.C.E. Graziano, G. Wolber, R. Maccari, Discovery of 4-[(5-arylidene-4-oxothiazolidin-3-yl)methyl]benzoic acid derivatives active as novel potent allosteric inhibitors of protein tyrosine phosphatase 1B: In silico studies and in vitro evaluation as insulinomimetic and anti-inflammatory agents, Eur. J. Med. Chem. 127 (2017) 840-858, https://doi.org/10.1016/j.ejmech.2016.10.063.

[38] R. Maccari, A. Del Corso, P. Paoli, I. Adornato, G. Lori, F. Balestri, M. Cappiello, A. Naß, G. Wolber, R. Ottanà, An investigation on 4-thiazolidinone derivatives as dual inhibitors of aldose reductase and protein tyrosine phosphatase $1 \mathrm{~B}$, in the search for potential agents for the treatment of type 2 diabetes mellitus and its complications, Bioorg. Med. Chem. Lett. 28 (2018) 3712-3720, https://doi.org/10. 1016/j.bmcl.2018.10.024.

[39] R. Maccari, P. Paoli, R. Ottanà, M. Jacomelli, R. Ciurleo, G. Manao, T. Steindl, T. Langer, M.G. Vigorita, G. Camici, 5-Arylidene-2,4-thiazolidinediones as inhibitors of protein tyrosine phosphatases, Bioorg. Med. Chem. 15 (2007) 5137-5149, https://doi.org/10.1016/j.bmc.2007.05.027.

[40] R. Ottanà, R. Maccari, R. Ciurleo, P. Paoli, M. Jacomelli, G. Manao, G. Camici, C. Laggner, T. Langer, 5-Arylidene-2-phenylimino-4-thiazolidinones as PTP1B and LMW-PTP inhibitors, Bioorg. Med. Chem. 17 (2009) 1928-1937, https://doi.org/ 10.1016/j.bmc.2009.01.044.
[41] R. Maccari, R. Ottanà, R. Ciurleo, P. Paoli, G. Manao, G. Camici, C. Laggner, T. Langer, Structure-based optimization of benzoic acids as inhibitors of protein tyrosine phosphatase 1B and low molecular weight protein tyrosine phosphatase, ChemMedChem 4 (2009) 957-962, https://doi.org/10.1002/cmdc.200800427.

[42] R. Ottanà, R. Maccari, S. Amuso, G. Wolber, D. Schuster, S. Herdlinger, G. Manao, G. Camici, P. Paoli, New 4-[(5-Arylidene-2-arylimino-4-oxo-3-thiazolidinyl)methyl] benzoic acids active as protein tyrosine phosphatase inhibitors endowed with insulinomimetic effect on mouse C2C12 skeletal muscle cells, Eur. J. Med. Chem. 50 (2012) 332-343, https://doi.org/10.1016/j.ejmech.2012.02.012.

[43] R. Ottanà, R. Maccari, J. Mortier, A. Caselli, S. Amuso, G. Camici, A. Rotondo, G. Wolber, P. Paoli, Synthesis, biological activity and structure-activity relationships of new benzoic acid-based protein tyrosine phosphatase inhibitors endowed with insulinomimetic effects in mouse C2C12 skeletal muscle cells, Eur. J. Med. Chem. 71 (2014) 112-127, https://doi.org/10.1016/j.ejmech.2013.11.001.

[44] R. Maccari, R. Ettari, I. Adornato, A. Naß, G. Wolber, A. Bitto, F. Mannino, F. Aliquò, G. Bruno, F. Nicolò, S. Previti, S. Grasso, M. Zappalà, R. Ottanà, Identification of 2-thioxoimidazolidin-4-one derivatives as novel noncovalent proteasome and immunoproteasome inhibitors, Bioorg. Med. Chem. Lett. 28 (2018) 278-283, https://doi.org/10.1016/j.bmcl.2017.12.053.

[45] G. Bruno, L. Costantino, C. Curinga, R. Maccari, F. Monforte, F. Nicolò, R. Ottanà, M.G. Vigorita, Synthesis and aldose reductase inhibitory activity of 5-arylidene-2,4thiazolidinediones, Bioorg. Med. Chem. 10 (2002) 1077-1084, https://doi.org/10. 1016/S0968-0896(01)00366-2.

[46] R. Ottanà, R. Maccari, M.L. Barreca, G. Bruno, A. Rotondo, A. Rossi, G. Chiricosta, R. Di Paola, L. Sautebin, S. Cuzzocrea, M.G. Vigorita, 5-Arylidene-2-imino-4-thiazolidinones: design and synthesis of novel antiinflammatory agents, Bioorg. Med. Chem. 13 (2005) 4243-4252, https://doi.org/10.1016/j.bmc.2005.04.058.

[47] P.J. Ala, L. Gonneville, M.C. Hillman, M. Becker-Pasha, M. Wei, B.G. Reid, R. Klabe, E.W. Yue, B. Wayland, B. Douty, P. Polam, Z. Wasserman, M. Bower, A.P. Combs, T.C. Burn, G.F. Hollis, R. Wynn, Structural basis for inhibition of protein-tyrosine phosphatase 1B by isothiazolidinone heterocyclic phosphonate mimetics, J. Biol. Chem. 281 (2006) 32784-32795, https://doi.org/10.1074/jbc.M606873200.

[48] C.A. Lipinski, F. Lombardo, B.W. Dominy, P.J. Feeney, Experimental and computational approaches to estimate solubility and permeability in drug discovery and development settings, Adv. Drug Deliv. Rev. 23 (1997) 3-25, https://doi.org/10. 1016/S0169-409X(00)00129-0.

[49] F. Wu, B. Zheng, H. Jiang, M. Kogiso, Y. Yao, C. Zhou, X.N. Li, Y. Song, Inhibition of cancer-associated mutant isocitrate dehydrogenases by 2 -thiohydantoin compounds, J. Med. Chem. 58 (2015) 6899-6908, https://doi.org/10.1021/acs. jmedchem.5b00684.

[50] B. Douty, B. Wayland, P.J. Ala, M.J. Bower, J. Pruitt, L. Bostrom, M. Wei, R. Klabe, L. Gonneville, R. Wynn, T.C. Burn, P.C. Liu, A.P. Combs, E.W. Yue, Isothiazolidinone inhibitors of PTP1B containing imidazoles and imidazolines, Bioorg. Med. Chem. Lett. 18 (2008) 66-71, https://doi.org/10.1016/j.bmcl.2007. 11.012 .

[51] G. Jones, P. Willett, R.C. Glen, A.R. Leach, R. Taylor, Development and validation of a genetic algorithm for flexible docking, J. Mol. Biol. 267 (1997) 727-748, https:// doi.org/10.1006/jmbi.1996.0897.

[52] Molecular Operating Environment (MOE), 201308; Chemical Computing Group ULC, 1010 Sherbrooke St West, Suite \#910, Montreal, QC, Canada, H3A 2R7, 2018. 